\title{
Taxonomic revision of the species of Stenothemus from Southwest China (Coleoptera, Cantharidae), with the descriptions of five new species
}

\author{
Yuxia YANG ${ }^{1, *}$, Shujuan $\mathrm{GE}^{2}$, Xingke YANG $^{3}$ \& Haoyu LIU ${ }^{4, *}$ \\ ${ }^{1,2,4}$ The Key Laboratory of Zoological Systematics and Application, School of Life Science, Institute of \\ Life Science and Green Development, Hebei University, Baoding 071002, Hebei Province, China. \\ ${ }^{3}$ Key Laboratory of Zoological Systematics and Evolution, Institute of Zoology, Chinese Academy of \\ Sciences, Beijing 100101, China. \\ *Corresponding authors: yxyang@hbu.edu.cn, liuhy@hbu.edu.cn \\ 2Email:1264084679@qq.com \\ ${ }^{3}$ Email: yangxk@ioz.ac.cn \\ ${ }^{1}$ urn:lsid:zoobank.org:author:5DE2E8C5-0E72-4E81-979F-AA3596D4D9F5 \\ ${ }^{2}$ urn:Isid:zoobank.org:author:EDE4D3AD-FC52-4537-AFED-99272F0960BE \\ ${ }^{3}$ urn:lsid:zoobank.org:author:8878D2C6-30E2-4C64-96EB-6BD8F03DB752 \\ ${ }^{4}$ urn:1sid:zoobank.org:author:9A257221-9F0A-4EC7-88E5-BC95AF249723
}

\begin{abstract}
The species of Stenothemus Bourgeois, 1907 from Southwest China are reviewed. Three species are transferred to this genus, $S$. davidi (Pic, 1926) comb. nov. (from Malthacus Kirby, 1837), S. minutissimus (Pic, 1933) comb. nov. (from Micropodabrus Pic, 1920) and S. singularicollis (Pic, 1933) comb. nov. (from Lycocerus Gorham, 1895). Two new synonyms are suggested, S. dinshuiensis Švihla, 2011 syn. nov. is synonymized with $S$. davidi and $S$. melleus Švihla, 2005 syn. nov. with $S$. singularicollis. Stenothemus shaanxiensis Švihla, 2004 stat. nov. is raised to species level from a subspecies of S. benesi Švihla, 2004. Five new species are described, S. gracilis Y. Yang \& X. Yang sp. nov., S. chongqingensis Y. Yang \& H. Liu sp. nov., S. flavicollis Y. Yang \& S. Ge sp. nov., S. jindraimimus Y. Yang \& X. Yang sp. nov. and S. laticornis Y. Yang \& H. Liu sp. nov., which are illustrated with photographs of habitus, aedeagi, abdominal sternites VIII and internal genitalia of the female. Characters of the female reproductive system are described for the first time for the following species: S. diffusus Wittmer, 1974, S. dundai Švihla, 2004, S. grahami Wittmer, 1974, S. jindrai Švihla, 2004, S. tryznai Švihla, 2004 and S. singularicollis. Some additional distribution information is added for previously known species. A key for the identification of all studied species is provided.
\end{abstract}

Keywords. Stenothemus, new species, new combination, new synonymy, new status.

Yang Y., Ge S., Yang X. \& Liu H. 2021. Taxonomic revision of the species of Stenothemus from Southwest China (Coleoptera, Cantharidae), with the descriptions of five new species. European Journal of Taxonomy 757: 1-36. https://doi.org/10.5852/ejt.2021.757.1409 


\section{Introduction}

The genus Stenothemus Bourgeois, 1907 is a moderately diverse group in Cantharidae Imhoff, 1856. In China, 59 species are recorded to date, accounting for about $70 \%$ of the total number of species worldwide (Yang et al. 2021; Ge et al. 2021). Following our previous works (Yang et al. 2014, 2021; Ge et al. 2021), we aim to revise the species from Southwest China in the present study. The species from Shaanxi, Gansu, Hubei, Guizhou, Chongqing and Sichuan provinces are studied here, but those from Yunnan and Xizang will be covered in a forthcoming work.

\section{Material and methods}

The material studied is preserved in the following collections, and the primary types were returned to the collections from which they were borrowed or were otherwise deposited in public museums.

The generic definition of Stenothemus follows that of Švihla (2004) in a broad sense. The methods are the same as those used in a previous paper (Yang et al. 2021). In studying the morphology of the aedeagus or the female genitalia, at least one specimen was dissected for the species, more if any damage occurred during dissection. If the species has a rather wide distribution range, one specimen was dissected from each locality. The measurements were carried out with the aid of a Leica M205A stereo microscope.

Morphological terminology of female genitalia follows Brancucci (1980).

Complete label data are listed for type specimens of the previously known species, using square brackets [ ] for our remarks and comments, [p] indicating that the following data are printed and [h] that they are handwritten. Quotation marks are used to separate data from different labels and double slashes // to separate data from different lines of the same label. For additional specimens, quotation marks are used if their original labels are written in English.

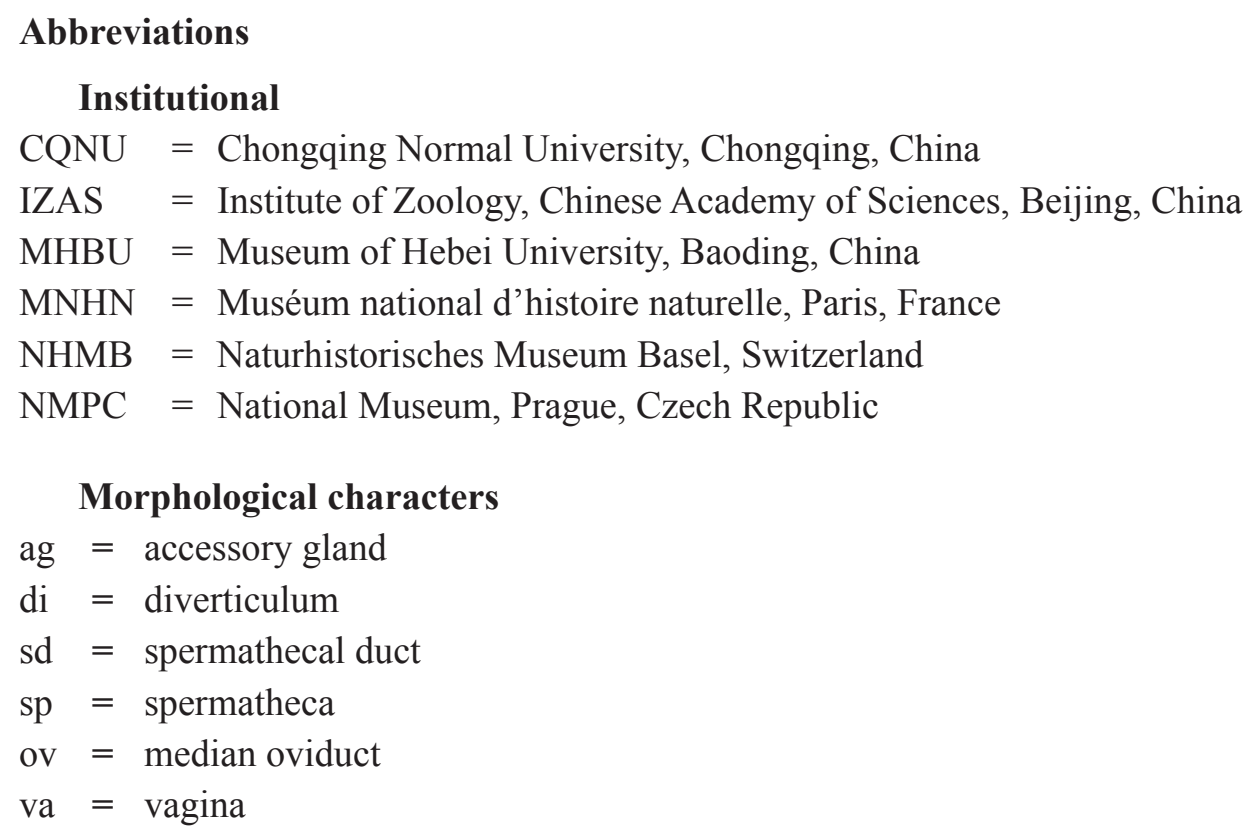




\section{Results}

\section{Taxonomic treatments}

Phylum Arthropoda Latreille, 1829

Class Insecta Linnaeus, 1758

Order Coleoptera Linnaeus, 1758

Superfamily Elateroidea Leach, 1815

Family Cantharidae Imhoff, 1856

Subfamily Cantharinae Imhoff, 1856

Genus Stenothemus Bourgeois, 1907

Stenothemus benesi Švihla, 2004

Fig. 1A

Stenothemus benesi Švihla, 2004: 202, figs 161-163, 214.

\section{Material examined}

Holotype

CHINA • Ō; [p] "China: C Sichuan 1993 // Luding Co. Moxi env. // V. Beneš lgt. 22.5.-10.6.", "HOLOTYPUS // Stenothemus // benesi sp. n. // V. Švihla det. 2003"; NMPC.

\section{Additional material}

CHINA - Sichuan • 1 ơ; Emei Shan; 2100-3100 m a.s.1.; 25 Jun. 1955; Bushchik leg.; IZAS. - Yunnan

• 2 ○ึ; “Bailakou pass 3750 m, 28 May-7 Jun. 2006, S. Murzin \& I. Shokhin leg.”; IZAS.

\section{Distribution}

China (Sichuan, Yunnan). New record for Yunnan Province.

\section{Remarks}

A type habitus photograph (Fig. 1A) is presented for the first time to allow comparison with the following species.

Stenothemus shaanxiensis Švihla, 2004 stat. nov.

Figs 1B, 2A-C, 3A, 4A

Stenothemus benesi shaanxiensis Švihla, 2004: 202, fig. 164.

\section{Material examined}

\section{Holotype}

CHINA - O’; [p] "China: Shaanxi 21.-23.6. // Quing Ling Shan Mts. 1998 // rd. Baoji-Taibai, 35 km S Baoji // O. Šafránek \& M. Trýzna lgt.", "HOLOTYPUS // Stenothemus // benesi shaanxiensis ssp. n. // V. Švihla det. 2003"; NMPC.

\section{Additional material}

CHINA - Chongqing • 1 ${ }^{\circ}$; Chengkou, Dong'an, Shengjiaping; $31.791^{\circ} \mathrm{N}, 109.241^{\circ} \mathrm{E} ; 1819 \mathrm{~m}$ a.s.l.; 16 Jun. 2017; B. Chen leg.; CQNU • 1 ते; Chengkou, Dong'an, Huang'anba Grassland; $31.846^{\circ} \mathrm{N}$, 109.199 Eं 2249 m a.s.1.; 15 Jun. 2017; B. Chen leg.; CQNU. - Shaanxi • 1 क; Zhouzhi, Houzhenzi; 1550-3000 m a.s.1.; 22 Jun. 1999; J. Hu leg.; IZAS • 1 क; Zhouzhi, Houzhenzi; 2500-3000 m a.s.1.; 22 Jun. 1999; C.M. Liu leg.; IZAS. 

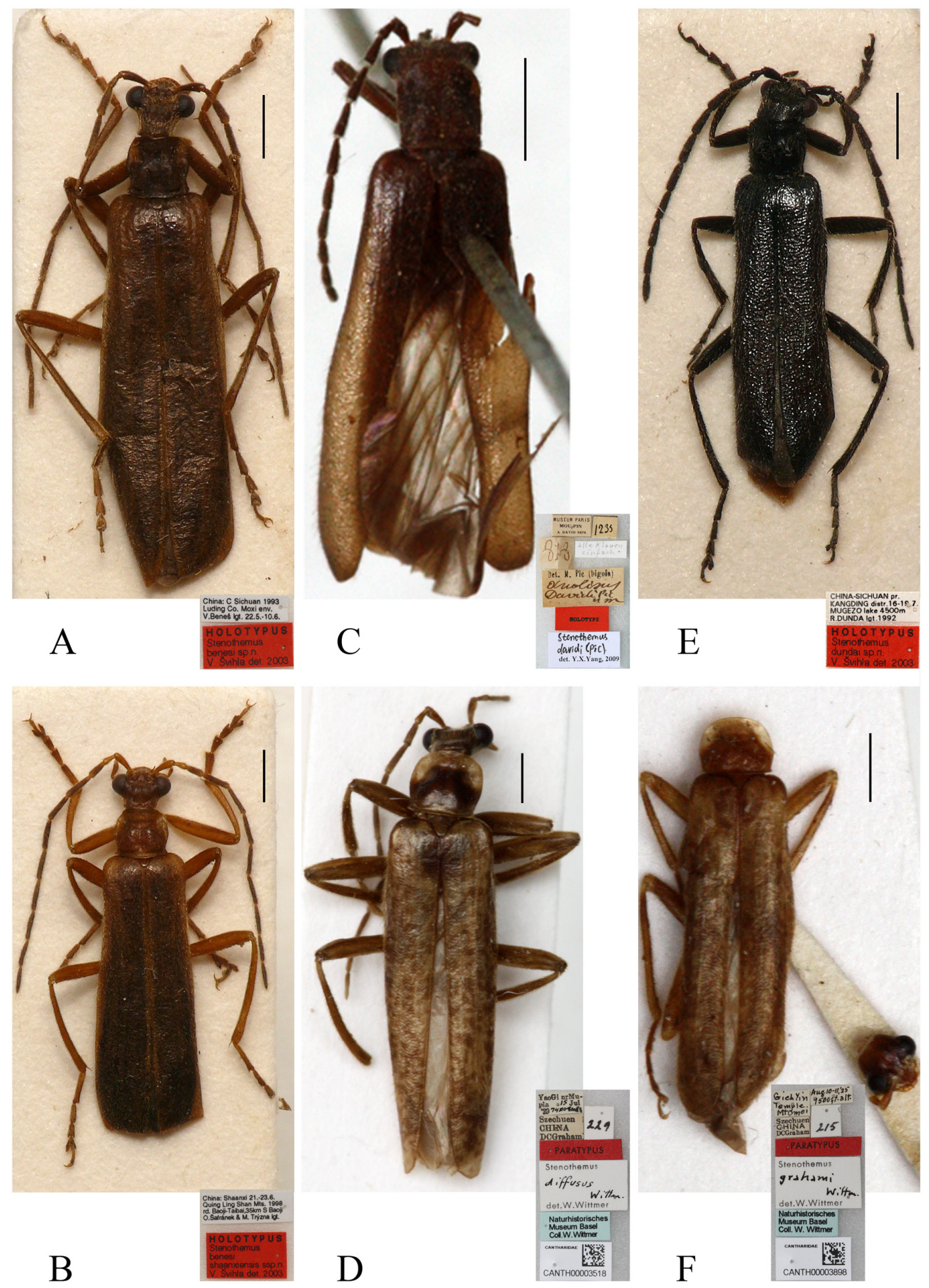

Fig. 1. Habitus, dorsal view. A. Stenothemus benesi Švihla, 2004, holotype, $\widehat{\partial}$ (NMPC). B. S. shaanxiensis Švihla, 2004 stat. nov., holotype, đ̊ (NMPC). C. S. davidi (Pic, 1926) comb. nov., holotype,, (MNHN). D. S. diffusus Wittmer, 1974, paratype, ô (NHMB CANTH00003518). E. S. dundai Švihla, 2004. holotype, ô (NMPC). F. S. grahami Wittmer, 1974, paratype, ô (NHMB CANTH00003898). Scale bars $=1.0 \mathrm{~mm}$. 

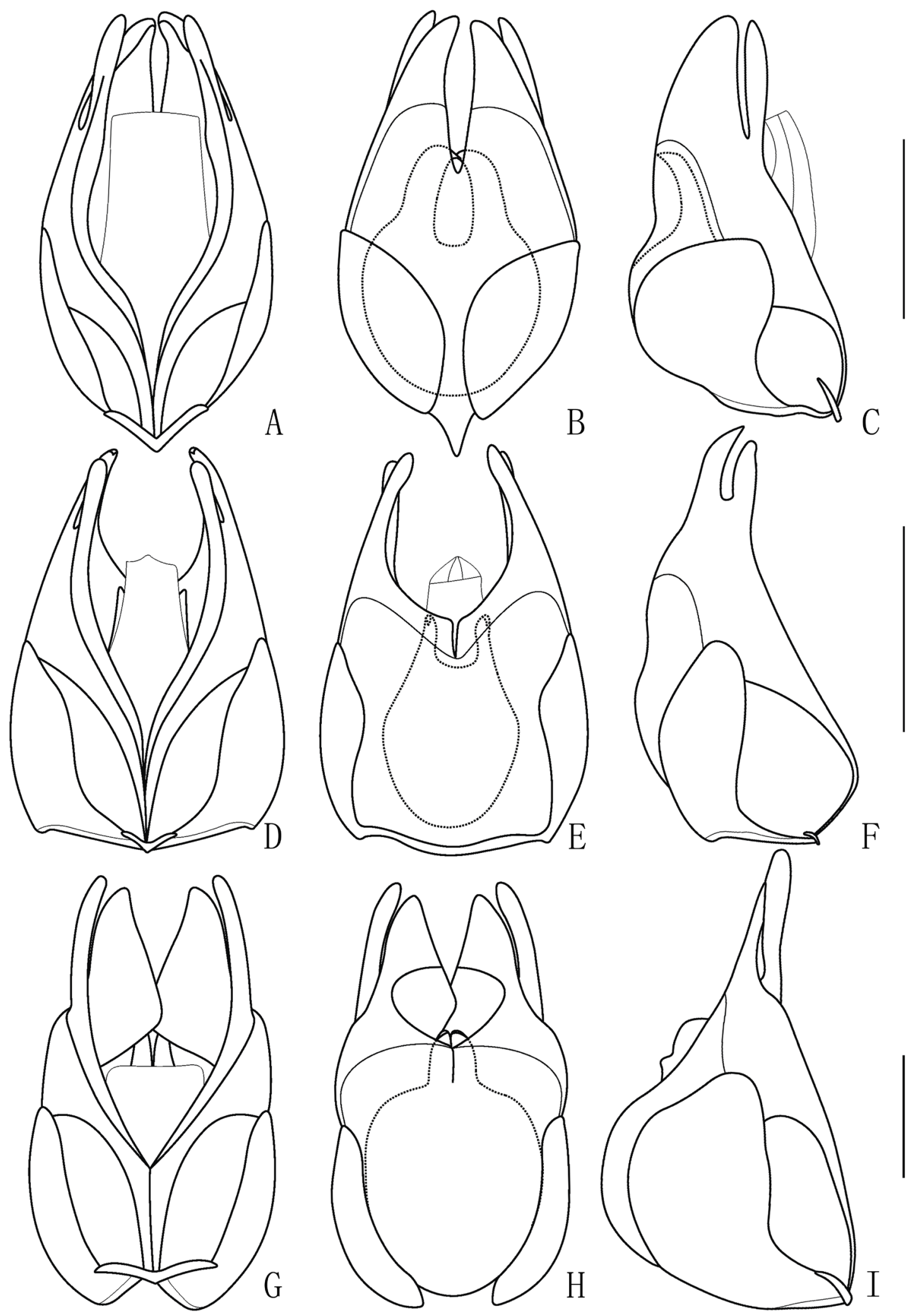

Fig. 2. Aedeagus (A, D, G = ventral view; B, E, H = dorsal view; $\mathrm{C}, \mathrm{F}, \mathrm{I}=$ lateral view). A-C. Stenothemus shaanxiensis Švihla, 2004 stat. nov. (CQNU, Chongqing). D-F. S. davidi (Pic, 1926) comb. nov. (IZAS, Sichuan). G-I. S. diffusus Wittmer, 1974 (MHBU, Sichuan). Scale bars $=0.5 \mathrm{~mm}$. 


\section{Descriptive notes}

Body length (both sexes): 5.5-8.3 mm; width: $1.5-2.6 \mathrm{~mm}$.

Male (Fig. 1B)

Aedeagus (Fig. 2A-C). Moderately swollen dorsally at basal part, moderately reduced basally in diameter; basal piece nearly as long as dorsal plate of each paramere, with a large, bifurcate conjoined middle nodule at base of ventral side; ventral processes of parameres nearly parallel to each other, long and slightly widened apically, nearly straight in lateral view; dorsal plate nearly as long as ventral process, evenly narrowed apically and next to each other, apex rounded and folded ventrally; apical parts of laterophyses depressed and approaching each other, apex acute and directed dorsally, slightly exceeding middle emargination between dorsal plates.

\section{Female}

AbDOMinal STERnite VIII (Fig. 3A). Obliquely narrowed posteriorly, lateroapical angles obtusely rectangular, posterior margin deeply and triangularly emarginate in middle and feebly sinuate on both sides, behind the notch with a membrane which is moderately sclerotized and triangularly bilobed at apex.

INTERNAL ORGAN OF REPRODUCTIVE SYSTEM (Fig. 4A). Vagina stout, with median oviduct situated at ventroapical part, vagina abruptly narrowed in apical part and extended into a long duct which diverticulum and spermathecal duct are arising from; diverticulum relatively short, about 0.33 times adult body length, evenly thinned apically, slender tube-shaped and spiral; spermathecal duct much shorter than diverticulum; spermatheca slender, tube-shaped and spiral, clearly thinner than spermathecal duct and slightly shorter than diverticulum, with basal part extended into a short tube, at opening of accessory gland. Accessory gland thin in basal part and the remainder moderately thin, nearly as long as spermatheca.

\section{Distribution}

China (Shaanxi, Chongqing). New record for Chongqing.

\section{Remarks}

In the original publication (Švihla 2004), this species was treated as a subspecies of S. benesi. However, differences between the two taxa are found not only in the external appearance, but also in the structures of the aedeagus. In S. shaanxiensis, the body is smaller and yellow (Fig. 1B), aedeagus (Fig. 2A-C) with the dorsal plate of each paramere approaching that of the other, and the ventral process of each paramere distinctly thickened apically. In contrast, in $S$. benesi, the body is larger and brown (Fig. 1A), aedeagus (Švihla 2004: figs 161-163) with dorsal plates of parameres separated from each other and ventral process of each paramere slightly thickened apically. These differences are sufficient to support their independent status, so it is proposed that $S$. shaanxiensis is separated from $S$. benesi and upgraded to the specific level. The dorsal and ventral view of the aedeagus and the female reproductive system for this species are described and illustrated for the first time.

Stenothemus davidi (Pic, 1926) comb. nov. Figs 1C, 2D-F, 3B, 4B

Anolisus davidi Pic, 1926: 357.

Stenothemus dinshuiensis Švihla, 2011: 18, fig. 20. syn. nov.

Podabrus (Dichelotarsus) davidi - Delkeskamp 1977: 32.

Dichelotarsus davidi - Kazantsev \& Brancucci 2007: 236.

Malthacus davidi - Takahashi 2007: 249. 


\section{Material examined}

\section{Holotype}

CHINA • +; [p] "MUSEUM PARIS // MOU. PIN / A. DAVID 1870”, [h] “1233”, “818”, “Alle Klauen // einfach", [h-p] "Det. M. Pic (Digoin) // Anolisus / Davidi Pic // n. sp.", [p] "HOLOTYPE", [h-p] "Stenothemus // davidi (Pic) // det. Y.X.Yang, 2009"; MNHN.

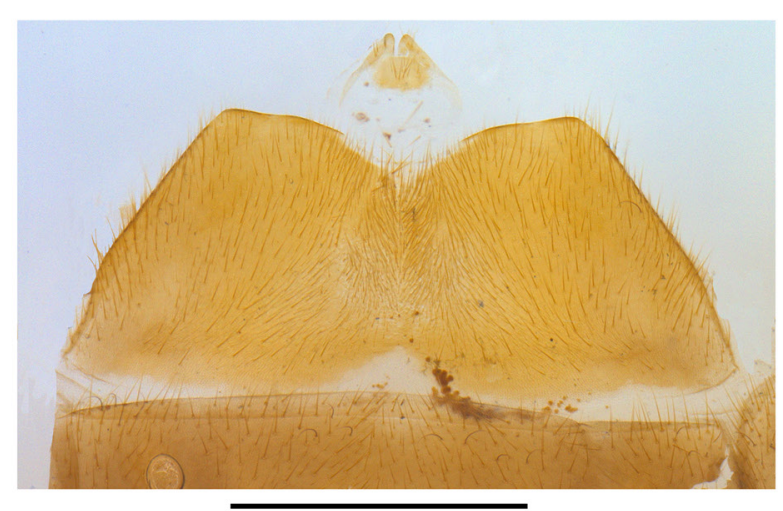

A

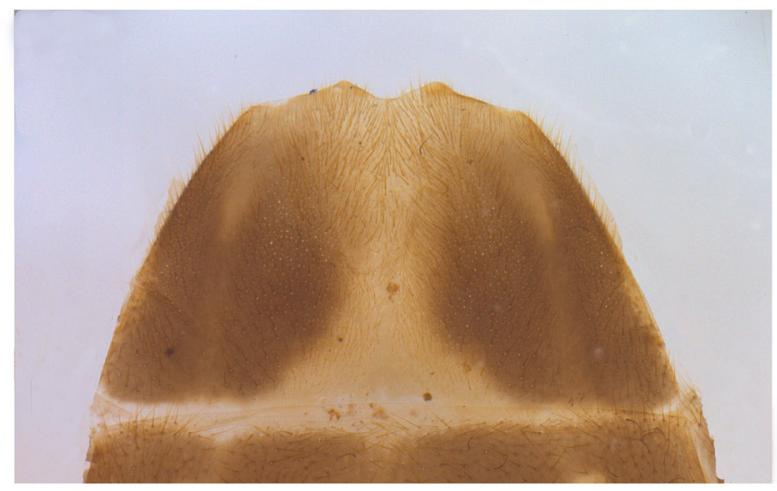

C

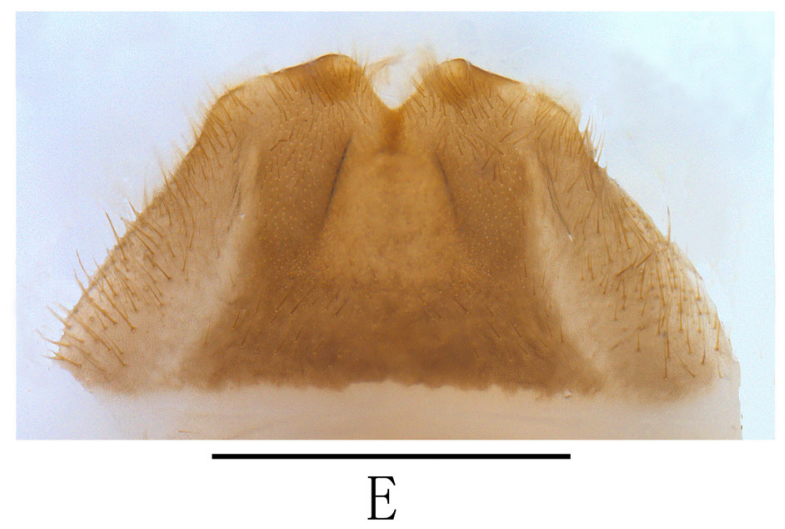

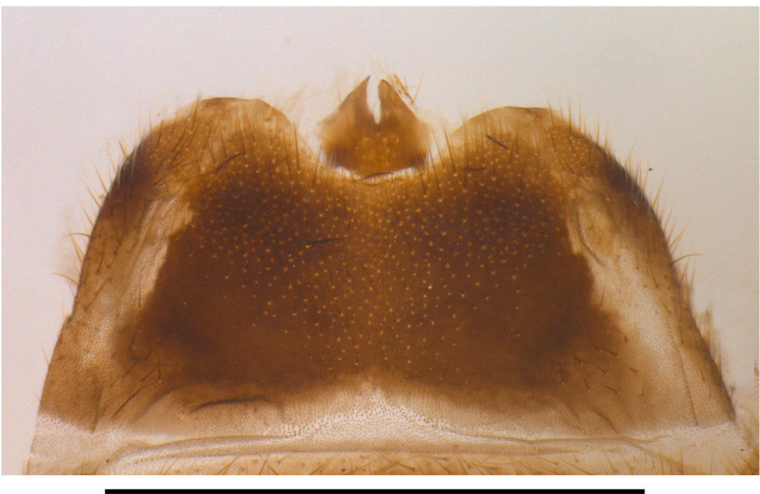

B

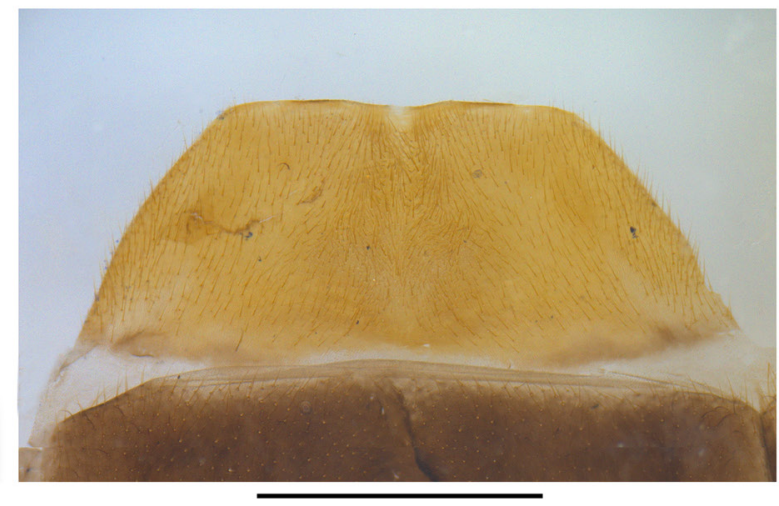

D

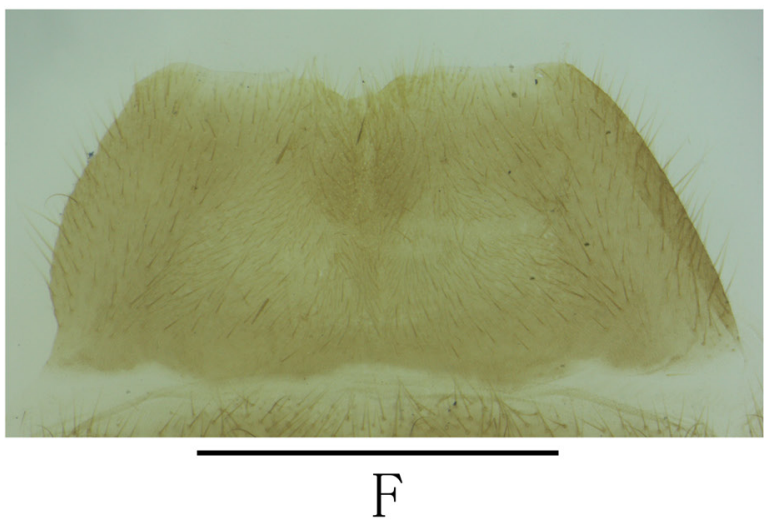

Fig. 3. Abdominal sternite VIII of female, ventral view. A. Stenothemus shaanxiensis Švihla, 2004 stat. nov. (IZAS, Shaanxi). B. S. davidi (Pic, 1926) comb. nov. (IZAS, Shaanxi). C. S. diffusus Wittmer, 1974 (MHBU, Sichuan). D. S. dundai Švihla, 2004 (MHBU, Sichuan). E. S. grahami Wittmer, 1974 (IZAS, Gansu). F. S. jindrai Švihla, 2004 (IZAS, Sichuan). Scale bars $=1.0 \mathrm{~mm}$. 


\section{Additional material}

CHINA - Shaanxi - 1 ふ઼; Daguping Protection Station - Yueba Protection Station; 30 Jun. 2012; W.G. Liu leg.; IZAS • 1 o; Qinling, Zhouzhi, Houzhenzi; 1276 m a.s.l.; 2 Jul. 2008; W.G. Liu leg.; IZAS. - Sichuan - 1 đ̊; Emei Shan, Baoguosi; 550-750 m a.s.1.; 10 May 1957; K.R. Huang leg.; IZAS • 1 ; ; same collection data as for preceding; 5 Jun. 1957; F.X. Zhu leg.; IZAS • 1 o; Emei Shan, Qingyin'ge; 800-1000 m a.s.1.; 7 May 1957; Z.Y. Wang leg.; IZAS • 1 §’; same collection data as for preceding; 9 May 1957; Y.C. Lu leg.; IZAS • 1 đ̊; Emei Shan; 1100-1800 m a.s.1.; 23 Jun. 1955; Z.L. Ge leg.; IZAS • 1 ठ̊?; Qingcheng Shan, Shangqinggong; 6600 m a.s.1.; 27 May 1979; P. Gao leg.; IZAS.

\section{Descriptive notes}

Body length (both sexes): 5.5-8.3 mm; width: 0.9-1.5 mm.

\section{Male}

Aedeagus (Fig. 2D-F). Moderately swollen laterally at basal part, moderately reduced apically in diameter; basal piece nearly as long as dorsal plate of each paramere, with a small, bifurcate conjoined middle nodule at base of ventral side; ventral processes of parameres nearly parallel to each other, moderately long and slightly thickened apically, bent ventrally in lateral view; dorsal plates slightly longer than ventral processes, strongly narrowed near base and approaching each other, apex acute and directed ventrally; apical parts of laterophyses depressed and separated from each other, apex acute and bent dorsally, roughly reaching middle emargination between dorsal plates.

Female (Fig. 1C)

Abdominal sternite VIII (Fig. 3B). Moderately narrowed posteriorly, lateroapical angles widely rounded, posterior margin widely and roundly emarginate in middle and feebly sinuate on both sides, behind the notch with a membrane which is sclerotized and triangularly bilobed at apex.

INTERNAL ORGAN OF REPRODUCtive system (Fig. 4B). Vagina stout, with median oviduct situated at ventroapical part, vagina abruptly narrowed in apical part and extended into a short duct which diverticulum and spermathecal duct are arising from; diverticulum moderately long, about 0.85 times adult body length, evenly thinned apically, slender tube-shaped and spiral; spermathecal duct slightly long but much shorter than diverticulum; spermatheca slender tube-shaped and spiral, obviously thinner than spermathecal duct and slightly shorter than diverticulum, with basal part extended into a short tube, at opening of accessory gland. Accessory gland thin in basal part and the remaining parts thick, much shorter than spermatheca.

\section{Distribution}

China (Sichuan, Shaanxi). New record for Shaanxi Province.

\section{Remarks}

The type (Fig. 1C) is seriously damaged, with right antenna, all legs except the left proleg one and abdomen missing, and with "alle Klauen einfach" ['all claws simple'] label attached, written by DrW.Wittmer. Fortunately, some additional material including males and females was available, enabling us to recognize it. The genitalia of both sexes are illustrated and described for the first time. Based on the structure of the aedeagus (Fig. 2D-F) and all simple claws, it definitely belongs to Stenothemus.

Furthermore, no difference is found from $S$. dinshuiensis, including overall appearance and structure of aedeagus, so it is considered to be a junior synonym of $S$. davidi. 


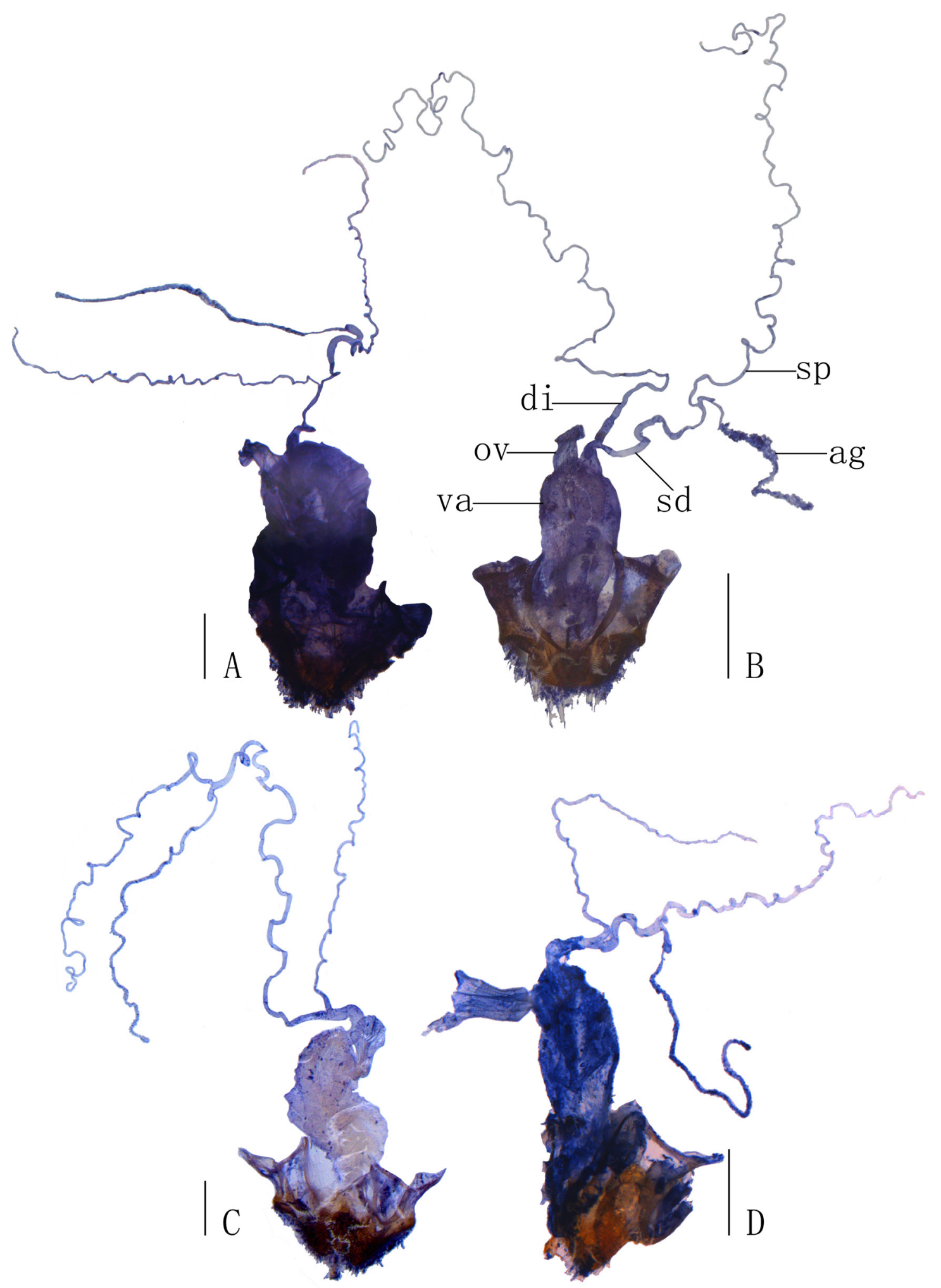

Fig. 4. Female reproductive system, ventral view. A. Stenothemus shaanxiensis Švihla, 2004 stat. nov. (IZAS, Shaanxi). B. S. davidi (Pic, 1926) comb. nov. (IZAS, Shaanxi). C. S. diffusus Wittmer, 1974 (MHBU, Sichuan). D. S. dundai Švihla, 2004 (MHBU, Sichuan). Abbreviations: see Material and methods. Scale bars $=0.5 \mathrm{~mm}$. 
Stenothemus diffusus Wittmer, 1974

Figs 1D, 2G-I, 3C, 4C

Stenothemus diffusus Wittmer, 1974: 58, fig. 17.

\section{Material examined}

\section{Paratype}

CHINA - 1 गे; [h-p] "Yao Gi nr Mu- // pin 15 Jul // '29 7400-8000ft", [p] "Szechuen // CHINA // D.C. Graham", [h] "119", [p] "PARATYPUS", [h-p] "Stenothemus // diffusus // Wittm. // det. W. Wittmer", [p] "Naturhistorisches // Museum Basel // Coll. W. Wittmer", "CANTHARIDAE // CANTH00003518"; NHMB.

\section{Additional material}

CHINA - Sichuan • 1 क; Wolong, Wolonggou; 2150 m a.s.1.; 21 Jul. 2004; X. Wan leg.; IZAS • 3 §ð, 7 우; Anzihe; 9 Aug. 2016; W.Y.Zhou leg.; MHBU • 1 §, 6 o $\circ$; Anzihe, Shaoyaogou; 1450 m a.s.l.;

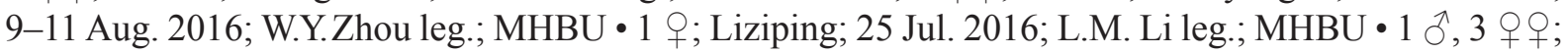
Baoxing, Kya'gyu Shan; 30 Jul. 2016; L.M. Li leg.; MHBU.

\section{Descriptive notes}

Body length (both sexes): 10.0-12.8 mm; width: 2.1-3.0 mm.

Male (Fig. 1D)

Aedeagus (Fig. 2G-I). Strongly swollen dorsally in basal part, diameter decreased apically; basal piece slightly shorter than dorsal plate of each paramere, with a large, bifurcate conjoined middle nodule at base of ventral side; ventral processes of parameres nearly parallel to each other, long and slightly thickened apically; dorsal plate slightly shorter than ventral process, evenly narrowed apically, layering in middle, external layer roundly emarginate in middle, internal layer deeply and triangularly emarginate, rounded at apex; apical parts of laterophyses compressed and next to each other, apex rounded and bent dorsally, slightly exceeding middle emargination between dorsal plates.

\section{Female}

ABDOMINAL STERNITE VIII (Fig. 3C). Obliquely narrowed posteriorly, lateroapical angles widely triangular, posterior margin shallowly and triangularly emarginate in the middle, and weakly sinuate on both sides.

INTERNAL ORGAN OF REPRODUCTIVE SYSTEM (Fig. 4C). Vagina elongate, with median oviduct situated at ventroapical part, vagina abruptly narrowed in apical part and extended into a short duct which diverticulum and spermathecal duct are arising from; diverticulum moderately long, about 0.35 times adult body length, evenly thinned apically, slender tube-shaped and spiral; spermathecal duct slightly longer than diverticulum; spermatheca slender tube-shaped and spiral, thinner than spermathecal duct and nearly as long as diverticulum, with basal part extended into a short tube, at opening of accessory gland. Accessory gland thin and nearly as long as spermatheca.

\section{Distribution}

China (Sichuan); Myanmar.

\section{Remarks}

The dorsal and lateral views of aedeagus and the female reproductive system are described and illustrated for the first time. 
Stenothemus dundai Švihla, 2004

Figs 1E, 3D, 4D

Stenothemus dundai Švihla, 2004: 199, figs 153-154, 212.

\section{Material examined}

\section{Holotype}

CHINA - ${ }^{\text {; }}$ [ [p] "CHINA-SICHUAN pr. // KANGDING distr. 16-19.7. // MUGEZO lake $4500 \mathrm{~m} / /$ R. DUNDA lgt. 1992”, "HOLOTYPUS // Stenothemus // dundai sp. n. // V. Švihla det. 2003”; NMPC.

\section{Additional material}

CHINA - Gansu • 1 §ึ, 2 q o ; Wenxian, Qiujiaba, Shiyaziliang; 3200-3400 m a.s.1.; 30 Jun. 1998; J. Yao leg.; IZAS • 1 ; same collection data as for preceding; J. Chen leg.; IZAS. - Qinghai • 1 o; Yushu,

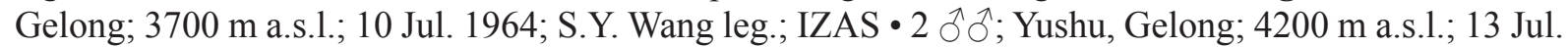
1964; S.Y. Wang leg.; IZAS. - Shaanxi • 2 9 9 ; Liuba, Dahongqu; 2500 m a.s.1.; 20 Jul. 1998; J. Chen leg.; IZAS. - Sichuan • 1 क; N Jiulong; 3735 m a.s.1.; 8-14 Jul. 2001; X.D. Yu and H.Z. Zhou leg.; IZAS

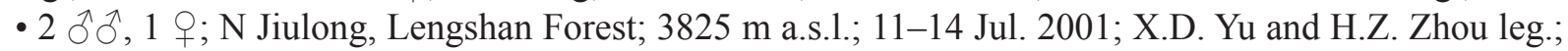

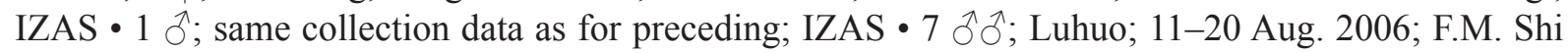
leg.; MHBU • 1 §ิ, 1 क; Jiangyuan, Shuajingsi; 27-28 Jul. 2009; Z.H. Gao and Y.P. Niu leg.; MHBU

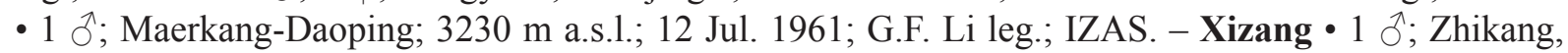

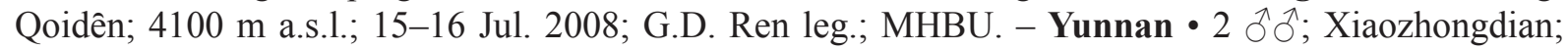
3800 m a.s.l.; 1 Aug. 1984; S.Y. Wang leg.; IZAS.

\section{Descriptive notes}

Body length (both sexes): 5.5-7.0 mm; width: 1.1-1.5 mm.

\section{Female}

AbDOMINAL Sternite VIII (Fig. 3D). Obliquely narrowed posteriorly, lateroapical angles widely triangular, posterior margin nearly straight and feebly emarginate in middle.

INTERNAL ORGAN OF REPRODUCTIVE SYSTEM (Fig. 4D). Vagina elongate, with median oviduct situated at ventroapical part, vagina abruptly narrowed in apical part and extended into a short duct which diverticulum and spermathecal duct are arising from; diverticulum relatively short, about 0.36 times adult body length, evenly thinned apically, slender tube-shaped and spiral; spermathecal duct slightly long but much shorter than diverticulum; spermatheca slender tube-shaped and spiral, obviously thinner than spermathecal duct and much longer than diverticulum, with basal part extended into a short tube, where accessory gland opens. Accessory gland thin and slightly shorter than spermatheca.

\section{Distribution}

China (Gansu, Qinghai, Shaanxi, Sichuan, Yunnan, Xizang). New records for Qinghai, Shaanxi, Yunnan.

\section{Remarks}

The female reproductive system is illustrated and described for the first time.

\section{Stenothemus grahami Wittmer, 1974}

Figs $1 \mathrm{~F}, 3 \mathrm{E}, 6 \mathrm{~A}-\mathrm{C}, 8 \mathrm{~A}$

Stenothemus grahami Wittmer, 1974: 60, fig. 18. 


\section{Material examined}

Paratype

CHINA • 1 § ; [h] "Gieh Yin // Temple // Mt. Omei”, “Aug. 10-11, '25 // 7500 ft. alt.”, [p] "Szechuen // CHINA // D. C. Graham", [h] "215", [p] "PARATYPUS", [h-p] "Stenothemus // grahami // Wittm. // det. W. Wittmer", [p] "Naturhistorisches // Museum Basel // Coll. W. Wittmer", "CANTHARIDAE // CANTH00003898"; NHMB.

\section{Additional material}

CHINA - Gansu • 1 $\delta^{\Uparrow}$; Longnan, Huixian, Yanping Forestry Farm; 20 Sep. 2020; J. Li leg.; MHBU - 1 ภ, 1 क; Tianshui, Naiji, Baihua; 17 Sep. 2020; J. Li leg.; MHBU • 1 ô; Tianshui, Naiji, Guanyin;

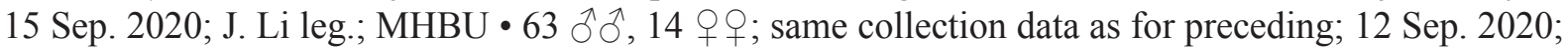
J. Li leg.; MHBU • 1 क; Zhugqu, Beach Forest Farm; 2400 m a.s.1.; 14 Jul. 1999; J. Yao leg.; IZAS •

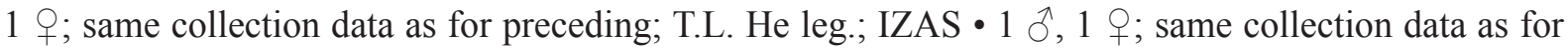
preceding; 2400 m a.s.l.; 16 Jul. 1999; J. Yao leg.; IZAS • 1 ; Wenxian, Qiujiaba; 2350 m a.s.l.; 21 Jul. 1999; T.L. He leg.; IZAS. - Henan • 1 ภ, 1 क; Songxian, Baiyun Shan; 14-17 Aug. 2008; G.D. Ren and Q.Q. Wu leg.; MHBU • 1 §’; Xixia, Baihe; 18 Aug. 2008; G.D. Ren and Q.Q. Wu leg.; MHBU. Hubei • 1 ک`; Xingshan, Longmenhe; $1100 \mathrm{~m}$ a.s.1.; 12 Sep. 1994; S.M. Song leg.; IZAS. - Shaanxi

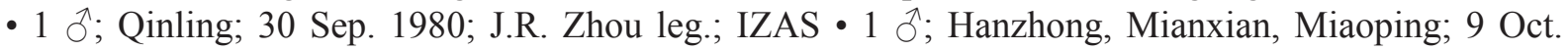
2020; J. Li leg.; MHBU. - Sichuan • 1 क; Jiuzhaigou; 7-15 Aug. 2002; M. Bai and J.F. Wang leg.; MHBU • 1 q; Danba, Kuiyonggou; 26 Aug. 2005; F.M. Shi leg.; MHBU • 1 đో; Emei Shan, Xixiangchi;

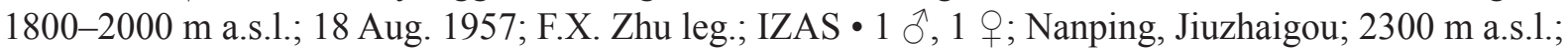
7 Sep. 1983; R.Q. Wang leg.; IZAS • 1 \%; Nanping, Jiuzhaigou; 2300 m a.s.1.; 4 Sep. 1983; X.Z. Zhang

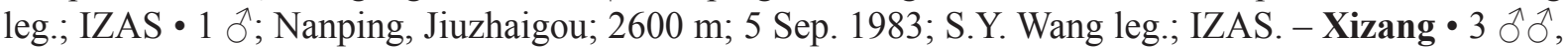
1 q; Zayü Xian, Cawarong, Longcun, Aga Inn; $28.5430^{\circ}$ N, $98.2348^{\circ}$ E; 2883 m a.s.1.; 8 Sep. 20I4; H. Liu leg.; IZAS • 1 § , 2 우; same collection data as for preceding; 9 Sep. 2014; H.B. Liang leg.; IZAS - 1 đ'; Zayü, Cawarong; $7500 \mathrm{~m}$ E of Jumuchang Inn; $28.5574^{\circ} \mathrm{N}, 98.2288^{\circ} \mathrm{E}$; $3060 \mathrm{~m}$ a.s.1.; 10 Sep. 2014; H. Liu leg.; IZAS • 1 क; Zayü, Cawarong, Longpu, Tangtuila Ya kou; $28.5424^{\circ} \mathrm{N}, 98.4587^{\circ} \mathrm{E}$; 3392 m a.s.1.; 15 Sep. 20I4; H.B. Liang leg.; IZAS.

\section{Descriptive notes}

Body length (both sexes): 7.2-10.6 mm; width: $1.5-2.5 \mathrm{~mm}$.

Male (Fig. 1F)

AEDEAGus (Fig. 6A-C). Strongly swollen dorsally at basal part, moderately reduced apically in diameter; basal piece slightly shorter than dorsal plate of each paramere, with a large, bifurcate conjoined middle nodule at base of ventral side; ventral processes of parameres nearly parallel to each other, moderately long and slightly narrowed apically, bent dorsally in lateral view; dorsal plate obviously longer than ventral process, evenly narrowed apically, apex rounded, outer margins folded ventrally; apical parts of laterophyses compressed and next to each other, apex acute and directed laterally, distinctly exceeding emargination between dorsal plates.

\section{Female}

AbDOMINAL STERNITE VIII (Fig. 3E). Obliquely narrowed posteriorly and slightly sinuate, lateroapical angles obtusely triangular, posterior margin deeply and triangularly emarginate in middle and widely truncate on both sides.

INTERNAL ORGAN OF REPRODUCTIVE SYSTEM (Fig. 8A). Vagina elongate, with median oviduct situated at ventroapical part, vagina abruptly narrowed in apical part and extended into a long duct which diverticulum and spermathecal duct are arising from; diverticulum relatively short, about 0.29 times adult body length, evenly thinned apically, slender tube-shaped and spiral; spermathecal duct slightly 
long but much shorter than diverticulum; spermatheca slender tube-shaped and spiral, obviously thinner than spermathecal duct and much longer than diverticulum, with basal part extended into a short tube, at opening of accessory gland. Accessory gland thin in basal part and the remainder moderately thin, nearly as long as spermatheca.

\section{Distribution}

China (Shaanxi, Gansu, Henan, Hubei, Sichuan, Xizang). New records for Shaanxi, Gansu, Henan, Hubei, Xizang.

\section{Remarks}

The female reproductive system and dorsal and lateral views of the aedeagus for this species are described and illustrated for the first time.

Stenothemus jindrai Švihla, 2004

Figs 3F, 5A, 8B

Stenothemus jindrai Švihla, 2004: 200, figs 157-158.

\section{Material examined}

Holotype

CHINA - O'; [p] "China-Sichuan // 5-9 July 1995 // Kangding env., 2400-2800 m // Zd. Jindra lgt.", "HOLOTYPUS // Stenothemus / jindrai sp. n. // V. Švihla det. 2003"; NMPC.

\section{Additional material}

CHINA - Sichuan • 1 \%; N Jiulong, Qinggang Forest; 3045 m a.s.1.; 8-14 Jul. 2001; X.D. Yu and H.Z. Zhou leg.; IZAS • 1 ภ, 1 क; Southwest Jiulong; $3320 \mathrm{~m}$ a.s.1.; 10-13 Jul. 2001; X.D. Yu and H.Z. Zhou leg.; IZAS • 1 \%; Southwest Jiulong; 3675 m a.s.1.; 10-13 Jul. 2001; X.D. Yu and H.Z. Zhou leg.; IZAS • 1 O’; Kangding, Huangjiagou; 2900 m; 4 Aug. 2004; Y. Zhang leg.; IZAS • 6 우; same collection data as for preceding; M. Bai leg.; IZAS • 1 क; Kangding, Moxi, Hailuogou; 3000 m a.s.l.; 8 Aug. 2004; X. Wan leg.; IZAS • 1 ô; Liziping, Menghuo, Pusagang Protection Station; $2481 \mathrm{~m}$ a.s.1.; 26 Jul. 2016; L.M. Li leg.; MHBU. - Yunnan • 1 J゙; Weixi, Pantian'ge; 2920 m a.s..1; 18 Jul. 1981; S.B. Liao leg.; IZAS.

\section{Descriptive notes}

Body length (both sexes): 7.5-10.0 mm; width: 1.4-2.0 mm.

\section{Female}

Abdominal sternite VIII (Fig. 3F). Moderately narrowed posteriorly, lateroapical angles widely triangular, posterior margin shallowly and roundly emarginate in middle and feebly emarginate on both sides.

INTERNAL ORGAN OF REPRODUCTIVE SYSTEM (Fig. 8B). Vagina stout, with median oviduct situated at ventroapical part, vagina abruptly narrowed in apical part and extended into a short duct which diverticulum and spermathecal duct are arising from; diverticulum relatively short, about 0.32 times adult body length, evenly thinned apically, slender tube-shaped and spiral; spermathecal duct slightly long but much shorter than diverticulum; spermatheca slender tube-shaped and spiral, obviously thinner than spermathecal duct and slightly longer than diverticulum, with basal part extended into a short tube, at opening of accessory gland. Accessory gland thin in basal part and the remainder moderately thin, slightly shorter than spermatheca. 

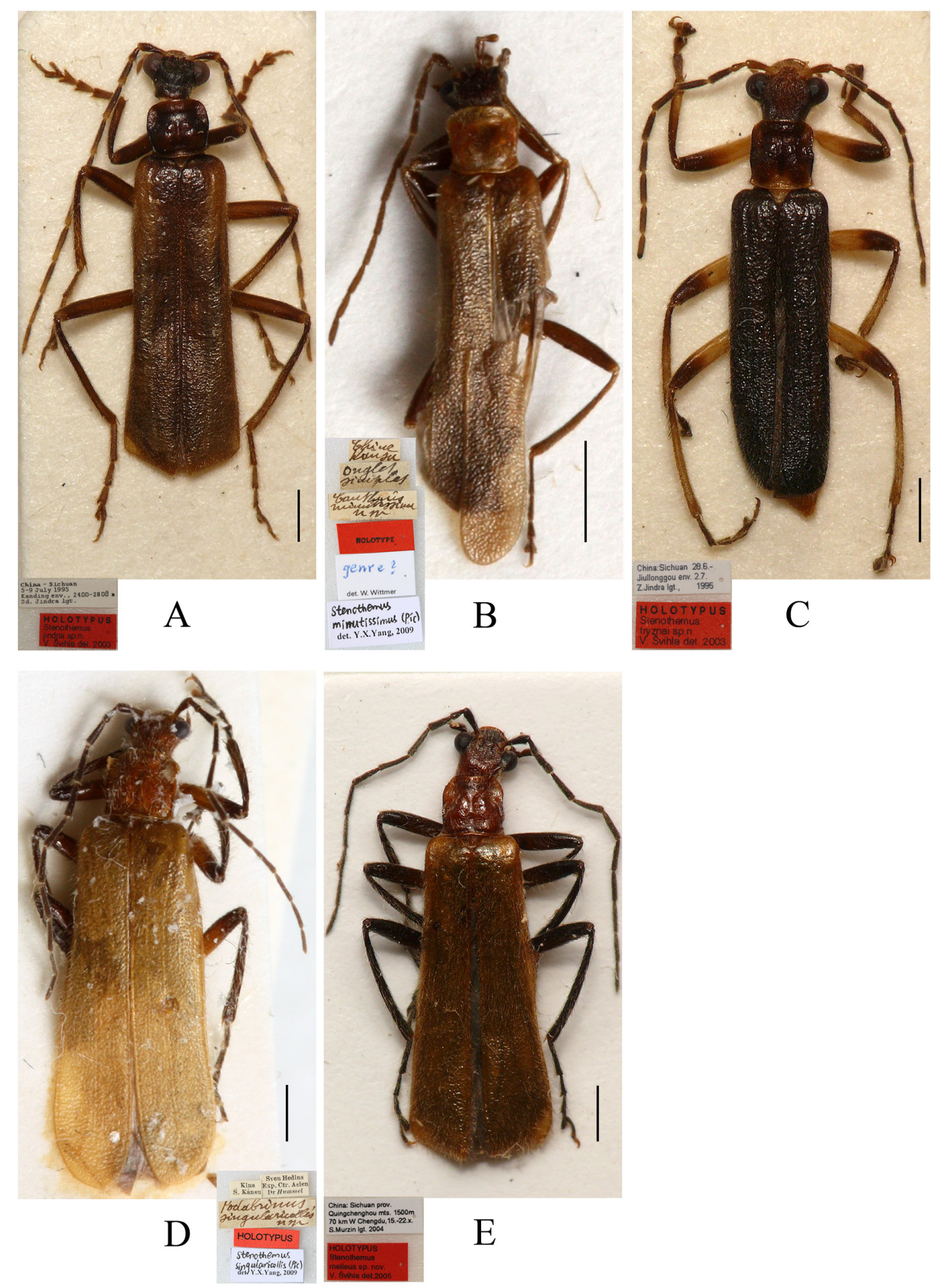

Fig. 5. Habitus, dorsal view. A. Stenothemus jindrai Švihla, 2004, holotype, $\widehat{\partial}$ (NMPC). B. S. minutissimus (Pic, 1933) comb. nov., holotype, §ิ (MNHN). C. S. tryznai Švihla, 2004, holotype, đิ (NMPC). D. S. singularicollis (Pic, 1933) comb. nov., holotype, $q$ (NHMH). E. S. melleus Švihla, 2005 syn. nov., holotype, $\widehat{\jmath}(=S$. singularicollis) (NMPC). Scale bars $=1.0 \mathrm{~mm}$. 


\section{Distribution}

China (Sichuan, Yunnan).

\section{Remarks}

The species was originally described from the male type, and subsequently Švihla (2011) described the female and illustrated abdominal sternite VIII. In the present study, the female reproductive system is described and illustrated for the first time.

\section{Stenothemus kansuensis Pic, 1933}

Stenothemus kansuensis Pic, 1933a: 4.

\section{Distribution}

China (Gansu).

\section{Remarks}

The type was not located in MNHN, but it was simply noted by Wittmer (1974) that the type is a female, with the body small and brown.

Stenothemus minutissimus (Pic, 1933) comb. nov. Figs 5B, 6D-F, 7A, 8C

Cantharis minutissima Pic, 1933b: 117.

Kandyosilis minutissima - Wittmer 1954: 76.

Micropodabrus minutissimus - Kazantsev \& Brancucci 2007: 257.

\section{Material examined}

\section{Holotype}

CHINA • गे; [h] "Chine // Kansu", "Ongles // simples", "Cantharis // minutissima // n. sp.”, [p] "HOLOTYPE", [h-p] "genre? // det. W.Wittmer", "Stenothemus // minutissimus (Pic) // det. Y. X. Yang, 2009"; MNHN.

\section{Additional material}

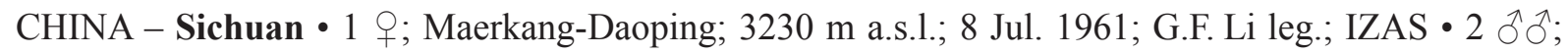

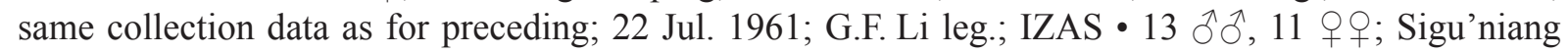
Shan, Changpinggou; 3300-3400 m a.s.1.; 31 Jul. 2004; H.J. Xue leg.; IZAS.

\section{Redescription}

Body length (both sexes): 5.0-6.3 mm; width: $1.0-1.4 \mathrm{~mm}$.

\section{Male (Fig. 5B)}

COLORATION. Body black, mouthparts and pronotum yellow, pronotum with an irregularly darkened marking on central disc, elytra brown. Body sparsely covered with short, semi-recumbent yellow pubescence.

HEAD. Subquadrate, surface densely and finely punctate, each side with a smooth and rectangular impression behind antennal socket; eyes moderately protruding, head width across eyes 1.4 times as wide as pronotum; terminal maxillary palpomeres long-triangular, widest in middle; antennae filiform, extending to $2 / 3$ length of elytra, antennomeres II about 1.8 times as long as wide at apices, III about 1.6 

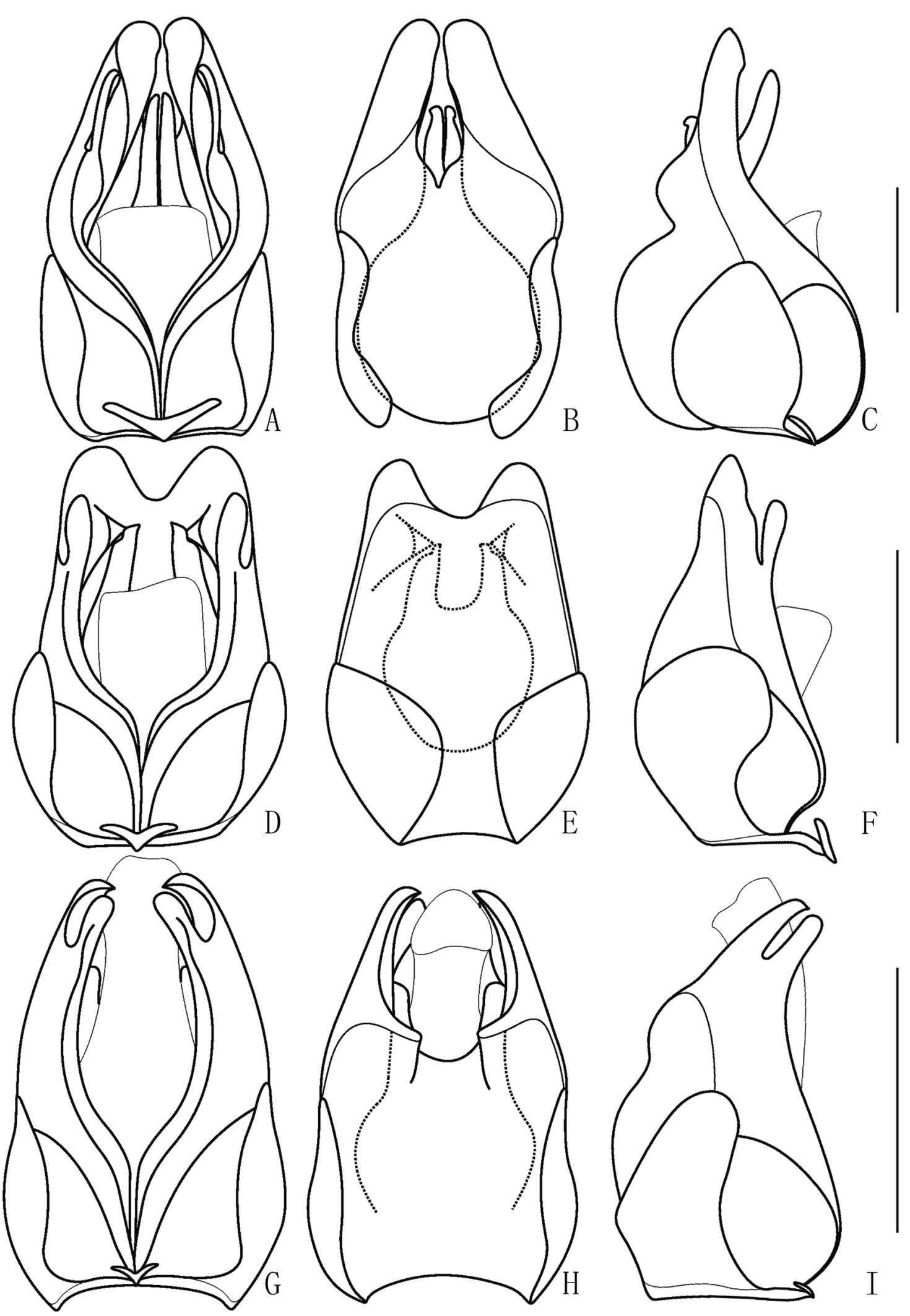

Fig. 6. Aedeagus (A, D, G = ventral view; B, E, H = dorsal view; C, F, I = lateral view). A-C. Stenothemus grahami Wittmer, 1974 (MHBU, Henan). D-F. S. minutissimus (Pic, 1933) comb. nov. (IZAS, Sichuan). G-I. S. gracilis Y. Yang \& X. Yang sp. nov. (MHBU HBU(E) 410022). Scale bars $=0.5 \mathrm{~mm}$. 
times as long as II, IV-XI each with a small and smooth longitudinal impression in middle of outer edge, VII longest, XI slightly longer than X, pointed at apex.

Pronotum. Subquadrate, about 1.1 times as long as wide, anterior margin nearly straight, anterior angles obtuse, widely truncate, lateral margins narrowed posteriorly, and slightly sinuate, posterior margin slightly sinuate, posterior angles obtuse, slightly protruding, disc distinctly convex on posterolateral parts, surface finely and densely punctate.

ELYTRA. Nearly parallel-sided, about 3.6 times as long as humeral width, 4.6 times longer than pronotum, surface finely and densely punctate, present with hardly visible longitudinal costae.

Aedeagus (Fig. 6D-F). Strongly swollen laterally at basal part, apically reduced in diameter; basal piece slightly shorter than dorsal plate of each paramere, with a moderately large, bifurcate conjoined middle nodule at base of ventral side; ventral processes of parameres nearly parallel to each other, short and distinctly thickened apically; dorsal plates of parameres conjoined, with a rounded emargination in the middle of the apical margin, distinctly longer than the ventral process, apex rounded, with a pair of protuberances on inner surface; apical part of laterophyses depressed and separated from each other, apex acute, not reaching middle emargination between dorsal plates.

\section{Female}

Similar to male, but body stouter, eyes small, less protruding, head width across eyes 1.2 times as wide as pronotum, antennae shorter and extending to elytral mid-length, IV-XI without impressions; elytra about 3.0 times as long as humeral width.

Abdominal sternite VIII (Fig. 7A). Moderately narrowed posteriorly, lateroapical angles obtusely triangular and protruding, posterior margin shallowly and triangularly emarginate in middle and slightly sinuate on both sides; behind the notch with a membrane, which is sclerotized and triangularly bilobed at apex.

INTERNAL ORGAN OF REPRODUCTIVE SYSTEM (Fig. 8C). Vagina stout, with median oviduct situated at ventroapical part, vagina abruptly narrowed in apical part and extended into a short duct which diverticulum and spermathecal duct are arising from; diverticulum relatively short, about 0.41 times adult body length, evenly thinned apically, slender tube-shaped and spiral; spermathecal duct slightly long but much shorter than diverticulum; spermatheca slender tube-shaped and spiral, obviously thinner than spermathecal duct and slightly longer than diverticulum, with basal part extended into a short tube, at opening of accessory gland. Accessory gland thin and slightly shorter than spermatheca.

\section{Distribution}

China (Gansu, Sichuan). New record for Sichuan Province.

\section{Remarks}

Having examined the type, and some additional specimens available, we redescribe this little-known species. Based on the structure of the aedeagus and all simple claws, it should be placed in Stenothemus.

Stenothemus tryznai Švihla, 2004

Figs $5 \mathrm{C}, 7 \mathrm{~B}, 8 \mathrm{D}$

Stenothemus tryznai Švihla, 2004: 197, figs 149-150, 213. 


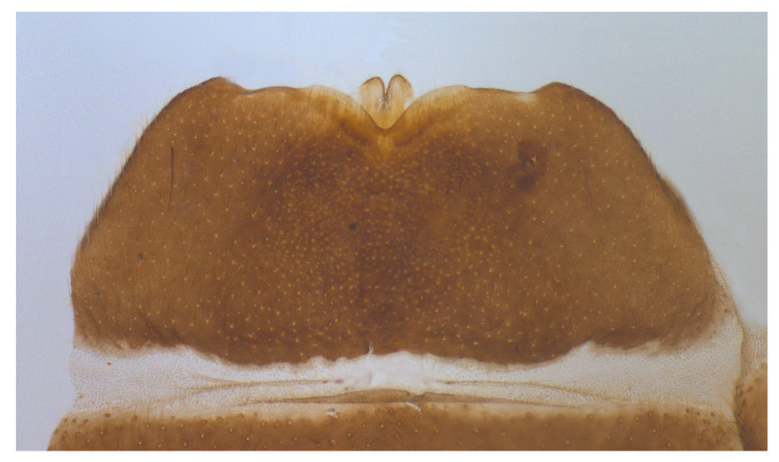

A
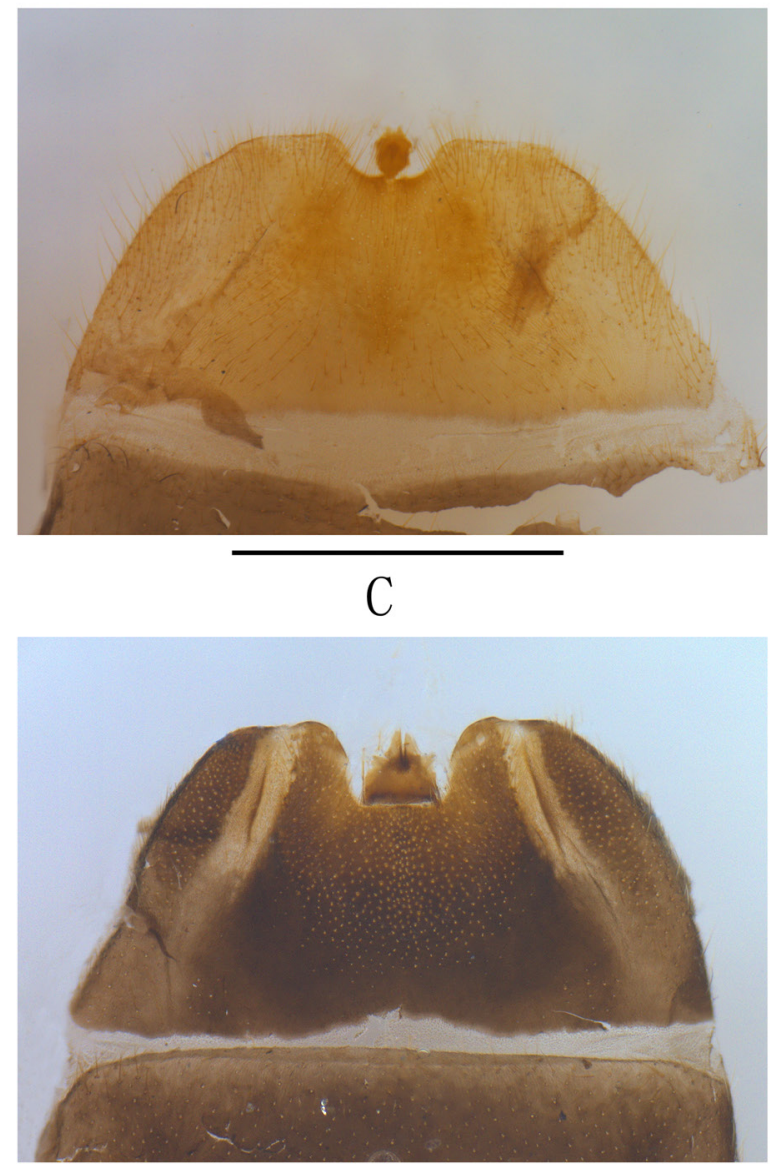

E

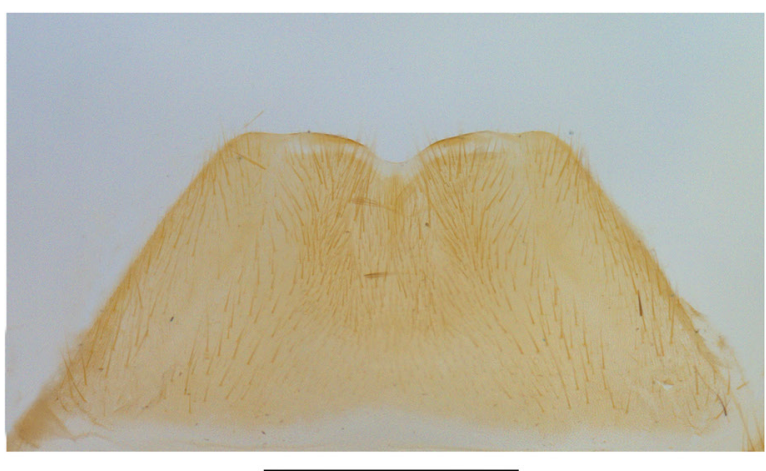

B
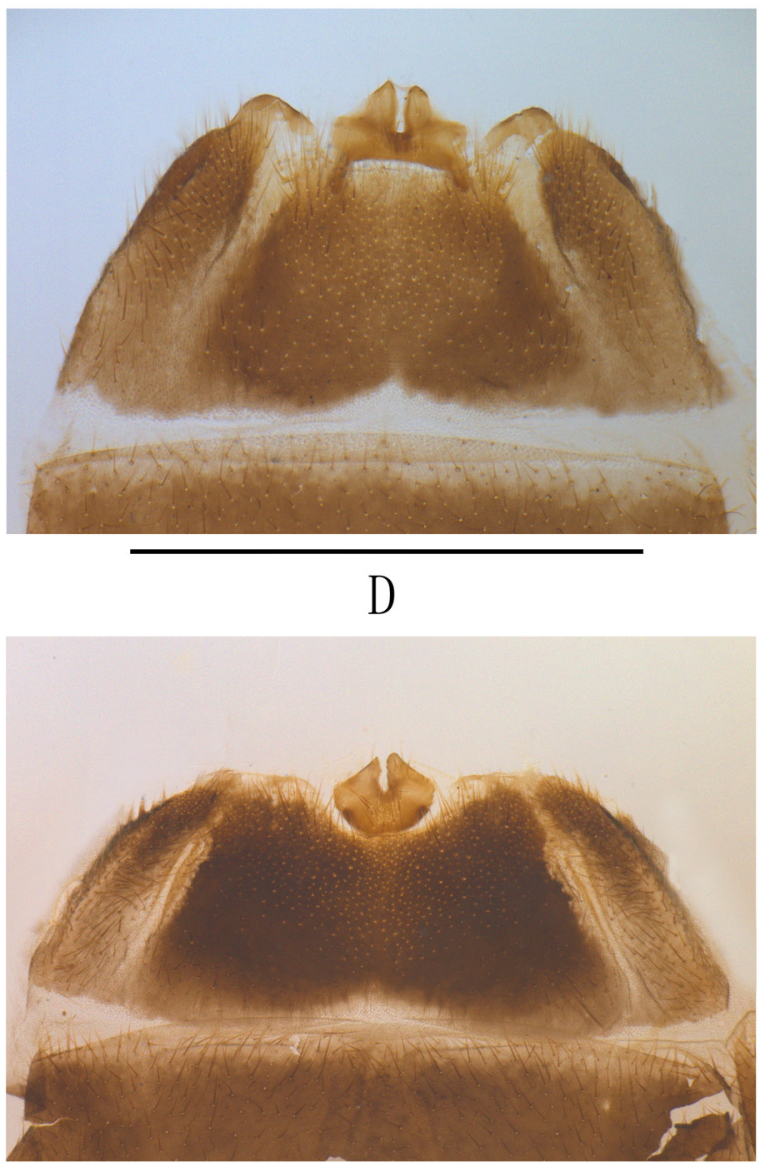

F

Fig. 7. Abdominal sternite VIII of female, ventral view. A. Stenothemus minutissimus (Pic, 1933) comb. nov. (IZAS, Sichuan). B. S. tryznai Švihla, 2004 (IZAS, Sichuan). C. S. singularicollis (Pic, 1933) comb. nov. (MHBU, Shaanxi). D. S. gracilis Y. Yang \& X. Yang sp. nov., paratype (IZAS IOZ(E) 225787). E. S. flavicollis Y. Yang \& S. Ge sp. nov., paratype (MHBU HBU(E) 410039). F. S. laticornis Y. Yang \& H. Liu sp. nov., paratype (MHBU HBU(E) 410047). Scale bars $=1.0 \mathrm{~mm}$. 


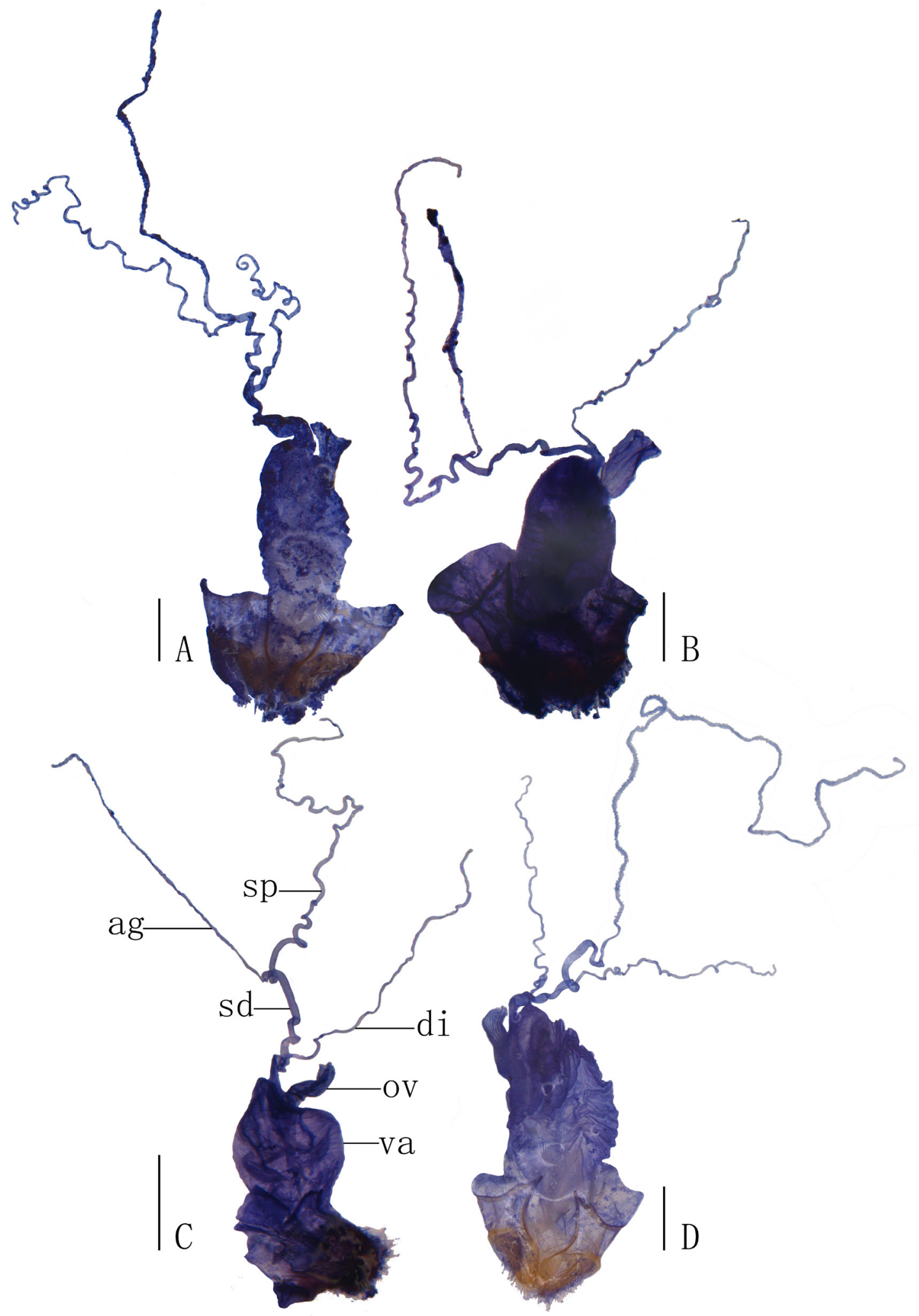

Fig. 8. Female reproductive system, ventral view. A. Stenothemus grahami Wittmer, 1974 (IZAS, Gansu). B. S. jindrai Švihla, 2004 (IZAS, Sichuan). C. S. minutissimus (Pic, 1933) comb. nov. (IZAS, Sichuan). D. S. tryznai Švihla, 2004 (IZAS, Sichuan). Abbreviations: see Material and methods. Scale bars $=0.5 \mathrm{~mm}$. 


\section{Material examined}

Holotype

CHINA • गे; [p] "China: Sichuan 28.6- // Jiulonggou env. 2.7. // Z. Jindra lgt., 1995", "HOLOTYPUS // Stenothemus // tryznai sp. n. // V. Švihla det. 2003”; NMPC.

\section{Additional material}

CHINA - Sichuan • 1 Oे, 1 क; Emei Shan, Jiulaodong; 1800-1900 m a.s.1.; 28 Jul. 1957; K.R. Huang

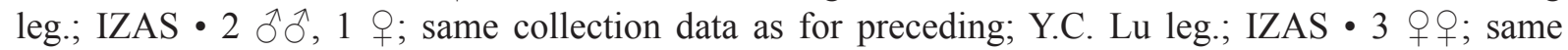
collection data as for preceding; 27 Jul. 1957; K.R. Huang leg.; IZAS • 1 q; same collection data as for

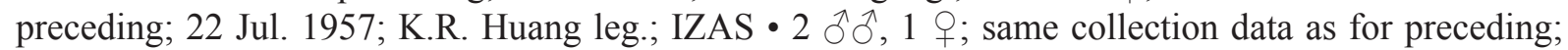
6 Jul. 1957; F.X. Zhu leg.; IZAS • 1 क ; same collection data as for preceding; 2 Aug. 1957; Y.C. Lu leg.; IZAS • 1 क; Emei Shan, Qingyin'ge; 800-1000 m a.s.1.; 13 Jun. 1957; Y.C. Lu leg.; IZAS • 1 ơ; Baoxing, Kya'gyu Shan; 2400 m a.s.1.; 30 Jul. 2016; L.M. Li leg.; MHBU.

\section{Descriptive notes}

Body length (both sexes): $8.0-11.5 \mathrm{~mm}$; width: $2.0-2.7 \mathrm{~mm}$.

\section{Female}

ABDOMINAL STERNITE VIII (Fig. 7B). Strongly narrowed posteriorly, lateroapical angles widely triangular, posterior margin shallowly and roundly emarginate in middle and feebly emarginate on both sides.

INTERNAL ORGAN OF REPRODUCTIVE SYSTEM (Fig. 8D). Vagina elongate, with median oviduct situated at ventroapical part, vagina abruptly narrowed in apical part and extended into a short duct which diverticulum and spermathecal duct are arising from; diverticulum relatively short, about 0.32 times adult body length, evenly thinned apically, slender tube-shaped and spiral; spermathecal duct much shorter than diverticulum; spermatheca slender tube-shaped and spiral, obviously thinner than spermathecal duct and nearly as long as diverticulum, with basal part extended into a slightly long tube, at opening of accessory gland. Accessory gland thin and much longer than spermatheca.

\section{Distribution}

China (Sichuan).

\section{Remarks}

The female reproductive system of this species is illustrated and described for the first time.

Stenothemus singularicollis (Pic, 1933) comb. nov.

Figs 5D-E, 7C, 12A

Podabrinus singularicollis Pic, 1933a: 5.

Stenothemus melleus Švihla, 2005: 103, fig. 71. syn. nov.

Pseudoabsidia singularicollis - Wittmer 1969: 128.

Athemellus singularicollis - Wittmer 1972: 124.

Lycocerus singularicollis - Kazantsev \& Brancucci 2007: 253.

\section{Material examined}

Holotype of Podabrinus singularicollis

CHINA • O; [p] "Kina // S. Kansu", "Sven Hedins // Exp. Ctr. Asien // Dr Hummel”, [h] "Podabrinus // singularicollis // n. sp.”, [p] "HOLOTYUS”, [h-p] "Stenothemus // singularicollis (Pic) // det. Y. X. Yang, 2009"; NHMH. 


\section{Holotype of Stenothemus melleus}

CHINA - O'; [p] "China: Sichuan Prov. // Quingchenghou mts. 1500 m// 70 km W Chengdu, 15.-22.x. // S. Murzin lgt. 2004”, [p] "HOLOTYUS // Stenothemus // melleus sp. nov. // V. Švihla det. 2005"; NMPC.

\section{Additional material}

CHINA - Gansu • 1 đ̧; Tianshui, Naiji, Guanyin; 12 Sep. 2020; J. Li leg.; MHBU. - Shaanxi • 1 đ; "China, Shaan Xi, Qin Ling Mountain, Hou Zhen Zi, 33.8463 N, 107.8333 ${ }^{\circ}$ E, 1350 m, 26 Aug. 2013,

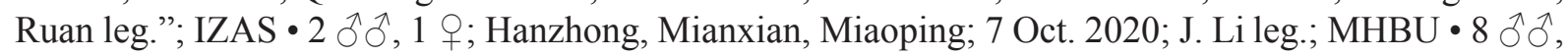
1 †; Hanzhong, Lueyang, Wulongdong; 11 Oct. 2020; J. Li leg.; MHBU • 1 क; Hanzhong, Liuba, Huoshaodian; 4 Oct. 2020; J. Li leg.; MHBU.

\section{Descriptive notes}

Body length (both sexes): $8.5-12.0 \mathrm{~mm}$; width: $1.8-2.5 \mathrm{~mm}$.

\section{Female}

ABDOMINAL SteRNITE VIII (Fig. 7C). Moderately narrowed posteriorly, lateroapical angles obtusely rounded, posterior margin widely and roundly emarginate in middle and feebly sinuate on both sides, behind the notch with a membrane which is sclerotized and triangularly bilobed at apex.

INTERNAL ORGAN OF REPRODUCTIVE SYSTEM (Fig. 12A). Vagina stout, with median oviduct situated at ventroapical part, vagina abruptly narrowed in apical part and extended into a short duct which diverticulum and spermathecal duct are arising from; diverticulum extremely long, about 0.58 times adult body length, evenly thinned apically, slender tube-shaped and spiral; spermathecal duct long but much shorter than diverticulum; spermatheca slender tube-shaped and spiral, thinner than spermathecal duct and nearly as long as diverticulum, with basal part extended into a short tube, where accessory gland opens. Accessory gland thin in basal part, and the remainder moderately thin, much shorter than spermatheca.

\section{Distribution}

China (Gansu, Sichuan, Shaanxi). New record for Shaanxi Province.

\section{Remarks}

Having examined the holotypes of Podabrinus singularicollis (Fig. 5D) and Stenothemus melleus (Fig. 5E), as well as a large series of additional specimens available, we are unable to find differences justifying their separation, which has led us to consider all the examined specimens to be conspecific. Therefore, we suggest the latter species should be synonymized with the former, which should be called S. singularicollis according to the structure of the aedeagus and simple claws. Additionally, the female reproductive system and abdominal sternite VIII of this species are described for the first time.

$$
\begin{gathered}
\text { Stenothemus gracilis Y. Yang \& X. Yang sp. nov. } \\
\text { urn:1sid:zoobank.org:act:FC569AB0-1536-4CFF-8A47-AB758A67F21D }
\end{gathered}
$$

Figs 6G-I, 7D, 9A, 12B

\section{Differential diagnosis}

This new species is most similar to $S$. limbatipennis (Pic, 1926), but can be distinguished by the following characters: antennomeres IV-XI each with a small oval impression in middle of outer edge in male (with longitudinal impressions in S. limbatipennis); pronotum about 1.3 times as long as wide (while nearly as long as wide in S. limbatipennis); aedeagus: ventral process of each paramere moderately bent ventrally in lateral view, middle emargination between dorsal plates longer than half its length, laterophyses clearly 
exceeding middle emargination (while ventral process strongly bent ventrally, middle emargination between dorsal plates shorter, apex of laterophyses just reaching in S. limbatipennis, see Yang et al. 2021: figs 3g-i); abdominal sternite VIII: lateroapical angles triangular and protruding, posterior margin rectangularly emarginate in middle, membrane strongly sclerotized and triangularly bilobed at apex (lateroapical angles widely rounded, middle emargination rounded, membrane weakly sclerotized and tapered at apex in S. limbatipennis, see Yang et al. 2021: fig. 8c); female internal organ of reproductive system: diverticulum obviously longer than spermatheca (while shorter in S. limbatipennis, see Yang et al. 2021: fig. 6c).

\section{Etymology}

The specific name is derived from the Latin 'gracilis' ('slender'), referring to its slender body.

\section{Material examined}

Holotype

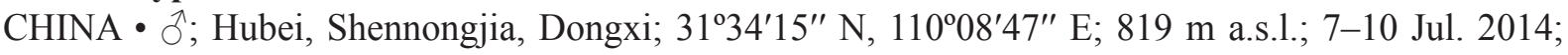
Y.B. Ba and S.Y.Tang leg.; MHBU HBU(E) 410022.

\section{Paratypes}

CHINA - Gansu • 2 ふふ઼; Wenxian, Liujiaping; 2100 m a.s.l.; 27 Jun. 1998; X.K. Yang leg.; IZAS IOZ(E) 225790, 225791. - Guizhou • 1 o; Daozhen, Yangxi, Shadang; 31 May 2004; Y. Yu leg.; MHBU

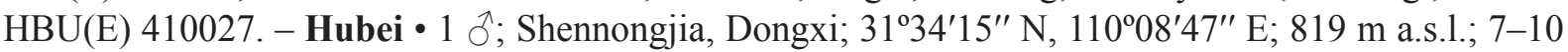
Jul. 2014; Y.B. Ba and S.Y. Tang leg.; MHBU HBU(E) 410023 • 1 ภ, 1 क; Shennongjia, Pingqian; $31^{\circ} 28^{\prime} 08.0^{\prime \prime} \mathrm{N}, 110^{\circ} 02^{\prime} 23.4^{\prime \prime} \mathrm{E} ; 1576 \mathrm{~m}$ a.s.1.; 4-7 Jul. 2014; Y.B. Ba and S.Y. Tang leg.; MHBU HBU(E) 410024, 410025 • 1 万; Shennongjia, Wenshui Forest Farm; 12 Jul. 2018; P. Wang leg.; MHBU HBU(E) 410026 • 1 §; Shennongjia, Songluo; 900 m a.s.1.; 14 Jun. 1981; Y.H. Han leg.; IZAS IOZ(E) 225781. -

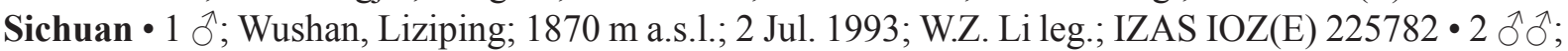

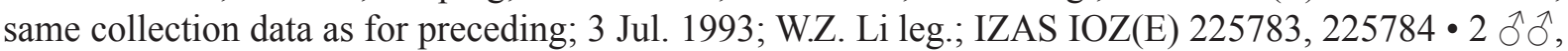

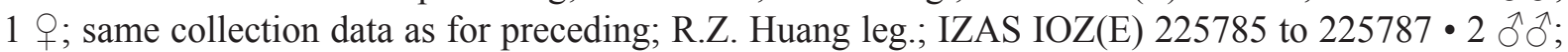
same collection data as for preceding; 4 Jul. 1993; R.Z. Huang leg.; IZAS IOZ(E) 225788, 225789.

\section{Description}

Body length (both sexes): 5.0-7.2 $\mathrm{mm}$ (5.8 $\mathrm{mm}$ in holotype); width: $0.5-1.0 \mathrm{~mm}(0.7 \mathrm{~mm}$ in holotype).

Male (Fig. 9A)

Coloration. Body brown, clypeus, mouthparts, posterior margins of abdominal ventrites lightly yellow. Body densely covered with short, semi-erected pale pubescence.

Head. Subquadrate, surface densely and finely punctate, each side with a smooth and rectangular impression behind antennal socket; eyes strongly protruding, head width across eyes 1.6 times wider than pronotum; terminal maxillary palpomeres long-triangular, widest in middle; antennae filiform, extending to $3 / 4$ length of elytra, antennomeres II about twice times as long as wide at apices, III about 1.8 times longer than II, IV-XI each with a small and smooth oval impression in middle of outer edge, VII longest, XI slightly longer than X, pointed at apex.

Pronotum. Subquadrate, about 1.3 times as long as wide, anterior margin slightly arcuate, anterior angles obtuse, sub-rectangular, lateral margins nearly parallel and slightly sinuate, posterior margin slightly arcuate and narrowly bordered, posterior angles sub-rectangular, disc distinctly convex on posterolateral parts, surface finely and densely punctate. 

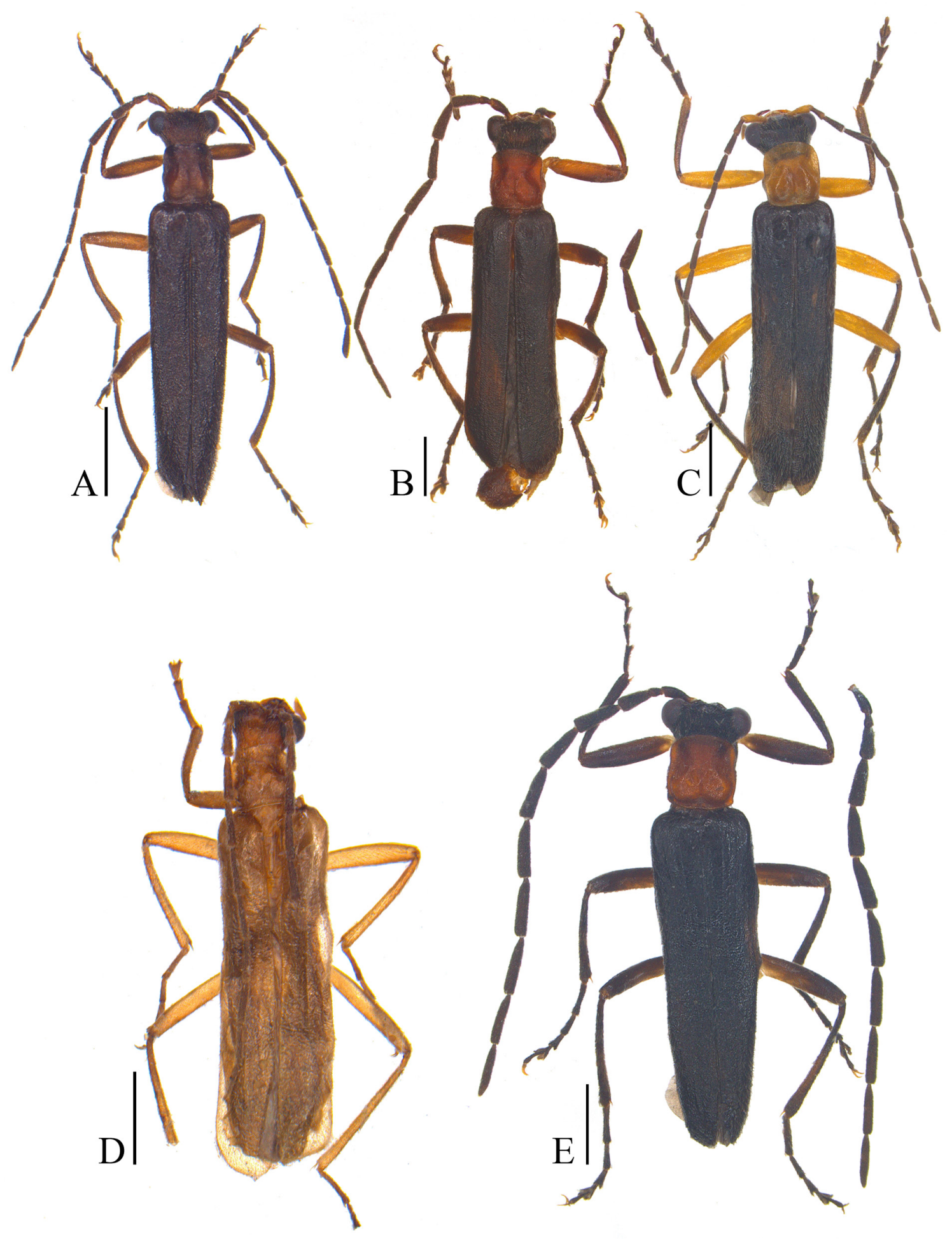

Fig. 9. Habitus, dorsal view. A. Stenothemus gracilis Y. Yang \& X. Yang sp. nov., holotype, $ð$ (MHBU HBU(E) 410022). B. S. chongqingensis Y. Yang \& H. Liu sp. nov., holotype, $\widehat{\partial}$ (MHBU HBU(E) 410028). C. S. flavicollis Y. Yang \& S. Ge sp. nov., holotype, ô (MHBU HBU(E) 410029). D. S. jindraimimus Y. Yang \& X. Yang sp. nov., holotype, ô (IZAS IOZ(E) 1389239). E. S. laticornis Y. Yang \& H. Liu sp. nov., holotype, ô (MHBU HBU(E) 410045). Scale bars $=1.0 \mathrm{~mm}$. 
ELYTRA. Nearly parallel-sided, about 3.8 times as long as humeral width, 4.9 times longer than pronotum, surface finely and densely punctate, with hardly visible longitudinal costae present.

Aedeagus (Fig. 6G-I). Moderately swollen laterally in basal part, reduced apically in diameter; basal piece nearly as long as dorsal plate of each paramere, with a small, bifurcate conjoined middle nodule at base of ventral side; ventral processes of parameres approaching each other, short and slightly thickened apically, bent ventrally in lateral view; dorsal plates slightly longer than ventral processes, strongly narrowed near base, approaching each other, apex acute and directed ventrally; apical parts of laterophyses depressed and separated from each other, apex rounded and bent dorsally, clearly exceeding middle emargination between dorsal plates.

\section{Female}

Similar to male, but body stouter than male, eyes small, less protruding, head width across eyes 1.2 times wider than pronotum, antennae shorter and roughly extending to elytral mid-length, IV-XI without smooth oval impressions; pronotum wider, nearly as long as wide; elytra about 3.3 times as long as humeral width.

Abdominal sternite VIII (Fig. 7D). Strongly narrowed posteriorly, lateroapical angles triangular and protruding, posterior margin widely and rectangularly emarginate in middle and feebly sinuate on both sides, behind the notch with a membrane which is sclerotized and triangularly bilobed at apex, with a rectangular sclerite present at center and a small longitudinal sclerite on each side.

INTERNAL ORGAN OF REPRODUCTIVE SYSTEM (Fig. 12B). Vagina stout, with median oviduct situated at ventroapical part, vagina abruptly narrowed in apical part and extended into a short duct which diverticulum and spermathecal duct are arising from; diverticulum extremely long, about 0.86 times adult body length, evenly thinned apically, slender tube-shaped and spiral; spermathecal duct much shorter than diverticulum; spermatheca slender tube-shaped and spiral, obviously thinner than spermathecal duct and much shorter than diverticulum, with basal part extended into a short tube, at opening of accessory gland. Accessory gland thin in basal part and the remainder thick, obviously shorter than spermatheca.

\section{Variation within species}

Head sometimes with yellow markings behind eyes, pronotum more or less lightened on posterolateral parts, elytra sometimes yellow at humeri and bases of outer margins.

\section{Distribution}

China (Hubei, Sichuan, Gansu, Guizhou).

Stenothemus chongqingensis Y. Yang \& H. Liu sp. nov. urn:1sid:zoobank.org:act:814D21FE-8EE1-49F5-ACFD-CC3E5398B8A1

Figs 9B, 10A-C

\section{Differential diagnosis}

Similar to S. laticornis Y. Yang \& H. Liu sp. nov., but differs in the following characters: male antennomeres IV-XI cylindrically thickened and each with a small and smooth longitudinal impression in middle of outer edge (while flattened and with oval impressions in S. laticornis sp. nov.); aedeagus: ventral process of each paramere slightly narrowed apically, bent ventrally in lateral view, apices of laterophyses not reaching middle emargination between dorsal plates (while ventral process distinctly thickened and bent dorsally in the S. laticornis sp. nov., and laterophyses exceeding middle emargination in S. laticornis sp. nov. (Fig. 11A-C)).

\section{Etymology}

The specific name is derived from the name of the type locality, Chongqing, China. 


\section{Material examined}

Holotype

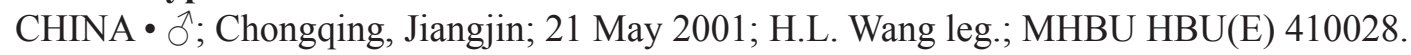

\section{Description}

Body length: $08.3 \mathrm{~mm}$; width: $2.2 \mathrm{~mm}$.

Male (Fig. 9B)

Coloration. Body brown, head, elytra black, with an orange marking at vertex, pronotum and scutellum testaceous, pronotum more or less lightened at anterior angles, prosternum, coxae and bases of inner margins of femora yellow. Body densely covered with short, semi-recumbent pale pubescence.

HEAD. Subquadrate, surface densely and finely punctate, each side with a smooth and rectangular impression behind antennal socket; eyes large, strongly protruding, head width across eyes 1.4 times as wide as pronotum; terminal maxillary palpomeres long-triangular, widest in middle; antennae filiform, almost reaching apices of elytra, antennomeres II about 1.5 times as long as wide at apices, III about 2.3 times longer than II, IV-XI cylindrically thickened and each with a small and smooth longitudinal impression in middle of outer edge, IV widest, V to XI gradually narrowing towards apex, XI slightly longer than X, pointed at apex.

Pronotum. Subquadrate, about 1.2 times as long as wide, anterior margin arcuate, anterior angles obtuse, sub-rectangular, lateral margins slightly sinuate, posterior margin slightly sinuate and narrowly bordered, posterior angles sub-rectangular, disc strongly convex on posterolateral parts, surface finely and densely punctate.

ELYTRA. Nearly parallel-sided, about 3.5 times as long as humeral width, 4.4 times longer than pronotum, surface finely and densely punctate, with hardly visible longitudinal costae.

AedeAgus (Fig. 10A-C). Moderately swollen laterally at basal part, strongly reduced in diameter apically; basal piece nearly as long as dorsal plate of each paramere, with a large, bifurcate conjoined middle nodule at base of ventral side; ventral processes parameres approaching each other, short and slightly narrowed apically, bent ventrally in lateral view; dorsal plates slightly longer than ventral processes, strongly narrowed near base, approaching each other, apex acute and directed ventrally; apical parts of laterophyses depressed and separated from each other, apex acute and not reaching middle emargination between dorsal plates.

\section{Female}

Unknown.

\section{Distribution}

China (Chongqing).

Stenothemus flavicollis Y. Yang \& S. Ge sp. nov. urn:1sid:zoobank.org:act:D0040599-E6AA-4A07-ACC5-EC916A4E9D9E

Figs 7E, 9C, 10D-F, 12C

\section{Differential diagnosis}

It resembles $S$. limbatipennis, but can be distinguished by the following characters: tibiae black (orange in S. limbatipennis); aedeagus: basal piece with a large middle nodule at base of ventral side, lateroapical part of dorsal plate with a longitudinal ridge, apical parts of laterophyses narrowly separated from each 
other, clearly exceeding middle emargination between dorsal plates (while middle nodule small, dorsal plate not ridged at lateroapical part, apical parts of laterophyses widely separated and just reaching middle emargination in S. limbatipennis, see Yang et al. 2021: figs 3g-i); female abdominal sternite VIII: posterior margin rectangularly emarginate in middle, membrane behind the middle emargination triangularly bilobed at apex (while roundly emarginate in middle, membrane behind the middle emargination tapered at apex in S. limbatipennis, see Yang et al. 2021: fig. 8c); female reproductive system: diverticulum and spermatheca extremely long (relatively short in $S$. limbatipennis, see Yang et al. 2021: fig. 6c).

\section{Etymology}

The specific name is derived from the Latin 'Alavus' ('yellow') and 'collum' ('neck'), referring to its yellow pronotum.

\section{Material examined}

\section{Holotype}

CHINA • ${ }^{\lambda}$; Hubei, Yichang, Dalaoling Forestry Farm; 3 May 2015; T.F. Qiu leg.; MHBU HBU(E) 410029 .

\section{Paratypes}

CHINA - Hubei $-8 \widehat{\partial}, 5$ $q$; same collection data as for holotype; MHBU HBU(E) 410030 to $410042 \cdot 1$ ô, 1 क; Yichang, Dalaoling Forestry Farm; 4 May 2015; T.F. Qiu leg.; MHBU HBU(E) $410043,410044$.

\section{Description}

Body length (both sexes): $6.5-9.7 \mathrm{~mm}$ (7.2 $\mathrm{mm}$ in holotype); width: $1.0-2.0 \mathrm{~mm}$ (1.7 $\mathrm{mm}$ in holotype).

Male (Fig. 9C)

Coloration. Body black, clypeus, mouthparts, antennomeres I, prothorax, coxae and femora and posterior margins of abdominal ventrites yellow. Body densely covered with short, semi-recumbent yellow pubescence.

HeAd. Subquadrate, surface densely and finely punctate, each side with a smooth and rectangular impression behind antennal socket; eyes moderately protruding, head width across eyes 1.5 times wider than pronotum; terminal maxillary palpomeres long-triangular, widest in middle; antennae filiform, roughly extending to $2 / 3$ length of elytra, antennomeres II about 2.2 times as long as wide at apices, III about 1.6 times longer than II, IV-XI each with a smooth longitudinal impression in middle of outer edge, VII longest, XI distinctly longer than X, XI slightly thickened, pointed at apex.

Pronotum. Subquadrate, about 1.1 times as long as wide, anterior margin arcuate, anterior angles subrounded, lateral margins nearly parallel and slightly sinuate, posterior margin slightly sinuate and narrowly bordered, posterior angles sub-rectangular, disc strongly convex on posterolateral parts, surface finely and densely punctate.

Elytra. Nearly parallel-sided, about 3.8 times as long as humeral width, 4.8 times longer than pronotum, surface finely and densely punctate, with hardly visible longitudinal costae.

Aedeagus (Fig. 10D-F). Moderately swollen laterally at basal part, reduced apically in diameter; basal piece nearly as long as dorsal plate of each paramere, with a large, bifurcate conjoined middle nodule at 

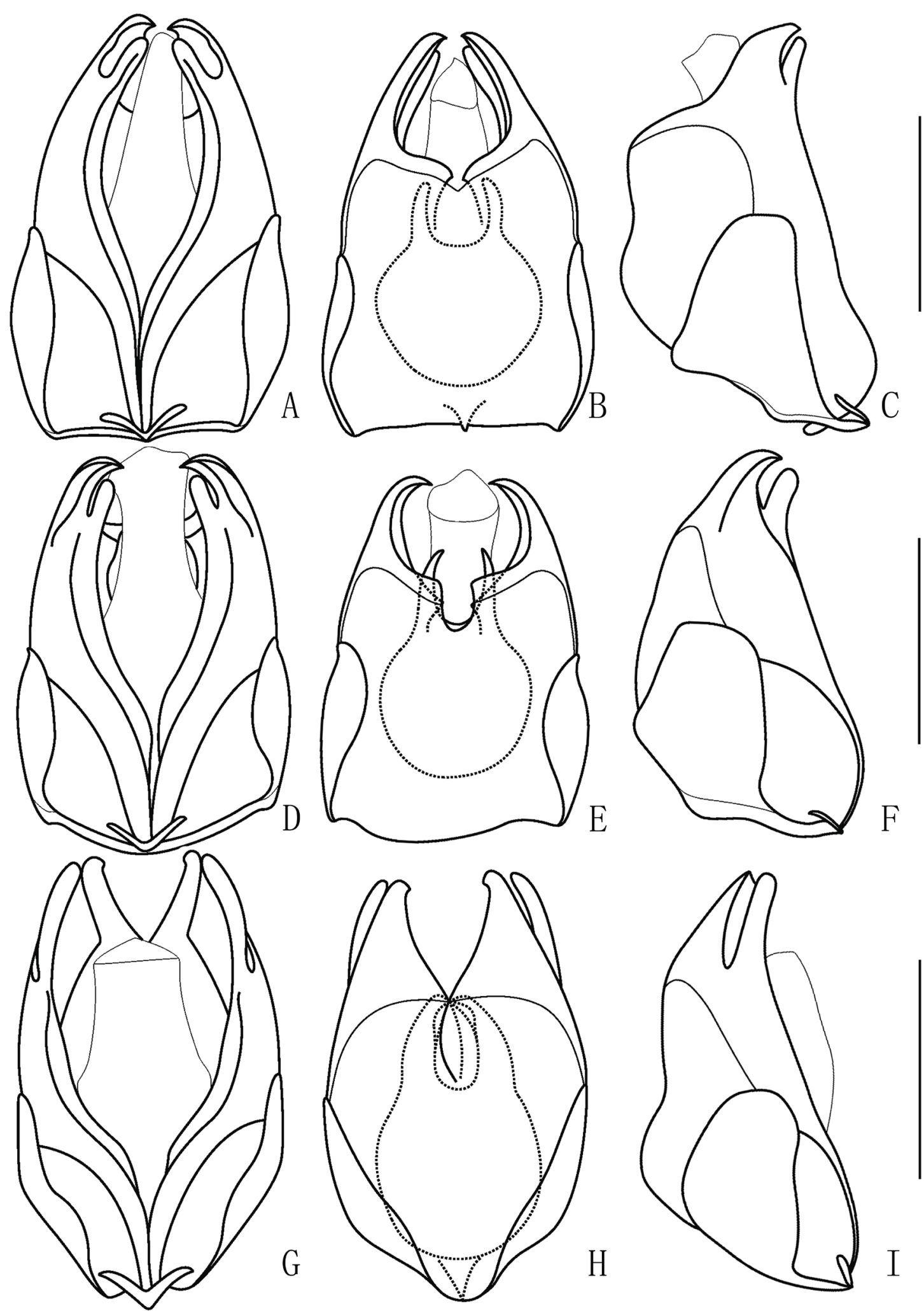

Fig. 10. Aedeagus (A, D, G = ventral view; B, E, H= dorsal view; $\mathrm{C}, \mathrm{F}, \mathrm{I}=$ lateral view). A-C. Stenothemus chongqingensis Y. Yang \& H. Liu sp. nov., holotype (MHBU HBU(E) 410028). D-F. S. flavicollis Y. Yang \& S. Ge sp. nov., holotype (MHBU HBU(E) 410029). G-I. S. jindraimimus Y. Yang \& X. Yang sp. nov., holotype (IZAS IOZ(E) 1389239). Scale bars: $0.5 \mathrm{~mm}$. 
base of ventral side; ventral processes of parameres approaching each other, short and slightly thickened apically, bent ventrally in lateral view; dorsal plates slightly longer than ventral processes, abruptly narrowed near base and approaching each other, apex acute and directed ventrally, lateroapical part with a ridge; apical parts of laterophyses depressed and separated from each other, apex acute and clearly exceeding middle emargination between dorsal plates.

\section{Female}

Similar to male, but body stouter than male, eyes small, less protruding, head width across eyes 1.3 times wider than pronotum, antennae shorter and roughly extending to elytral mid-length, IV-XI without smooth longitudinal impressions; elytra about 3.4 times as long as humeral width.

AbDOMINAL SteRnite VIII (Fig. 7E). Moderately narrowed posteriorly, lateroapical angles widely rounded, posterior margin widely and rectangularly emarginate in middle and feebly sinuate on both sides, behind the notch with a membrane which is sclerotized and triangularly bilobed at apex.

INTERNAL ORGAN OF REPRODUCTIVE SYSTEM (Fig. 12C). Vagina elongate, with median oviduct situated at ventroapical part, vagina abruptly narrowed in apical part and extended into a short duct which diverticulum and spermathecal duct are arising from; diverticulum extremely long, about 0.99 times adult body length, evenly thinned apically, slender tube-shaped and spiral; spermathecal duct slightly long but much shorter than diverticulum; spermatheca slender tube-shaped and spiral, obviously thinner than spermathecal duct and much longer than diverticulum, with basal part extended into a short tube, at opening of accessory gland. Accessory gland thin in basal part and remainder moderately thin, obviously shorter than spermatheca.

\section{Variation within species}

Sometimes posterior margin of pronotum arcuate.

\section{Distribution}

China (Hubei).

Stenothemus jindraimimus Y. Yang \& X. Yang sp. nov. urn:lsid:zoobank.org:act:3BA9E362-3F39-4413-B04B-FF1CB6549998

Figs 9D, 10G-I

\section{Differential diagnosis}

Resembles S. jindrai (Fig. 5A), but differs in the following characters: pronotum and elytra uniformly light yellow, while pronotum dark brown, lightened at anterior angles, elytra honey yellow, sienna at humeri and outer part in S. jindrai; aedeagus: apex of dorsal plate slightly narrowed, middle emargination between dorsal plates moderately deep, nearly as long as half its length, apical parts of laterophyses reaching middle emargination between dorsal plates, while dorsal plate strongly narrowed, middle emargination much longer than half length, laterophyses clearly exceeding middle emargination in $S$. jindrai (Švihla 2004: figs 155-156).

\section{Etymology}

The specific name is derived from the Latin 'mimus' ('imitate'), and the name of the similar species S. jindrai. 


\section{Material examined}

Holotype

CHINA • O'; Sichuan, Emei Shan, Xixiangchi; 1800-2000 m a.s.1.; 11-12 May 1957; F.X. Zhu leg.; IZAS IOZ(E) 1389239.

\section{Description}

Body length: ô $6.6 \mathrm{~mm}$; width: $1.5 \mathrm{~mm}$.

Male (Fig. 9D)

Coloration. Body light yellow, head, mouthparts, antennae and tarsi light brown. Body densely covered with short, semi-recumbent yellow pubescence.

HeAD. Subquadrate, surface sparsely and finely punctate, each side with a smooth and rectangular impression behind antennal socket; eyes strongly protruding, head width across eyes 1.5 times wider than pronotum; terminal maxillary palpomeres long-triangular, widest in middle; antennae filiform, extending $3 / 4$ of the length of elytra, antennomeres II about 1.7 times as long as wide at apices, III about 1.9 times longer than II, IV longest, XI slightly longer than X, pointed at apex.

Pronotum. Subrounded, about 0.9 times as long as wide, anterior margin nearly straight, anterior angles roundly truncate, lateral margins slightly sinuate, posterior margin nearly straight and narrowly bordered, posterior angles sharp, protruding, disc distinctly convex on posterolateral parts, surface finely and densely punctate.

ELYTRA. Nearly parallel-sided, about 3.7 times as long as humeral width, 6.1 times as long as pronotum, surface finely and densely punctate, with hardly visible longitudinal costae.

Aedeagus (Figs 10G-I). Weakly swollen dorsally in basal part, reduced basally in diameter; basal piece slightly shorter than dorsal plate of each paramere, with a large, bifurcate conjoined middle nodule at base of ventral side; ventral processes of parameres approaching each other, long and slightly narrowed apically, bent ventrally in lateral view; dorsal plates slightly longer than ventral processes, evenly narrowed apically, apex slightly acute and bent ventrally, outer margins of dorsal plates folded ventrally; apical parts of laterophyses depressed and next to each other in middle, apex acute, reaching middle emargination between dorsal plates.

\section{Female}

Unknown.

\section{Distribution}

China (Sichuan).

Stenothemus laticornis Y. Yang \& H. Liu sp. nov. urn:lsid:zoobank.org:act:C54780B5-A2AF-4FC8-B8A7-6AE3D067D8DF

Figs 7F, 9E, 11A-C, 12D

\section{Differential diagnosis}

It appears to resemble $S$. hajeki Švihla, 2011 (from China: N Yunnan), but differs in the following characters: apices of femora yellow, while uniformly black in $S$. hajeki; antennae almost reaching apices of elytra, while clearly exceeding them in $S$. hajeki (Švihla 2011: fig. 19); aedeagus: ventral processes of parameres strongly approaching each other, distinctly thickened apically and bent dorsally, while in S. hajeki (Švihla 2011: figs 93-95) the slightly approach each other, and are slightly thickened and bent ventrally. 


\section{Etymology}

The specific name is derived from the Latin 'latus' ('wide') and 'cornus' ('horn'), referring to its flattened and widened antennae.

\section{Material examined}

\section{Holotype}

CHINA - ${ }^{\top}$; Chongqing, Chengkou, Zuolan, Qixin; $32.180^{\circ}$ N, $108.485^{\circ}$ E; 1070 m a.s.1.; 9 Jul. 2017; Y. Zhou leg.; MHBU HBU(E) 410045.

\section{Paratypes}

CHINA - Chongqing • $1 \mathrm{O}^{\lambda}$; Chengkou, Dong'an, Shengiiaping; $31.791^{\circ} \mathrm{N}, 109.241^{\circ} \mathrm{E} ; 1819 \mathrm{~m}$ a.s.l.; 16 Jun. 2017; Y. Zhou leg.; MHBU HBU(E) 410046 • 1 q; Chengkou, Xianyi, Mingyue; 1184 m a.s.l.; 24 Jun. 2017; Y. Zhou leg.; MHBU HBU(E) 410047.

\section{Description}

Body length (both sexes): $7.2-8.0 \mathrm{~mm}$ (7.2 $\mathrm{mm}$ in holotype); width: $1.5-1.8 \mathrm{~mm}$ (1.7 $\mathrm{mm}$ in holotype).

\section{Male (Fig. 9E)}

Coloration. Body black, clypeus, mouthparts and bases of femora light yellow, pronotum testaceous, lightened at anterior angles. Body densely covered with short, semi-recumbent pale pubescence.

HEAD. Subquadrate, surface densely and finely punctate, each side with a smooth and rectangular impression behind antennal socket; eyes strongly protruding, head width across eyes 1.5 times wider than pronotum; terminal maxillary palpomeres long-triangular, widest at basal $2 / 3$; antennae filiform, almost reaching apices of elytra, antennomeres II about 1.1 times as long as wide at apices, III about 2.9 times longer than II, IV-XI flattened and each with a small and smooth oval impression in middle of outer edge, IV widest, V to XI gradually narrowing towards apex, XI slightly longer than X, pointed at apex.
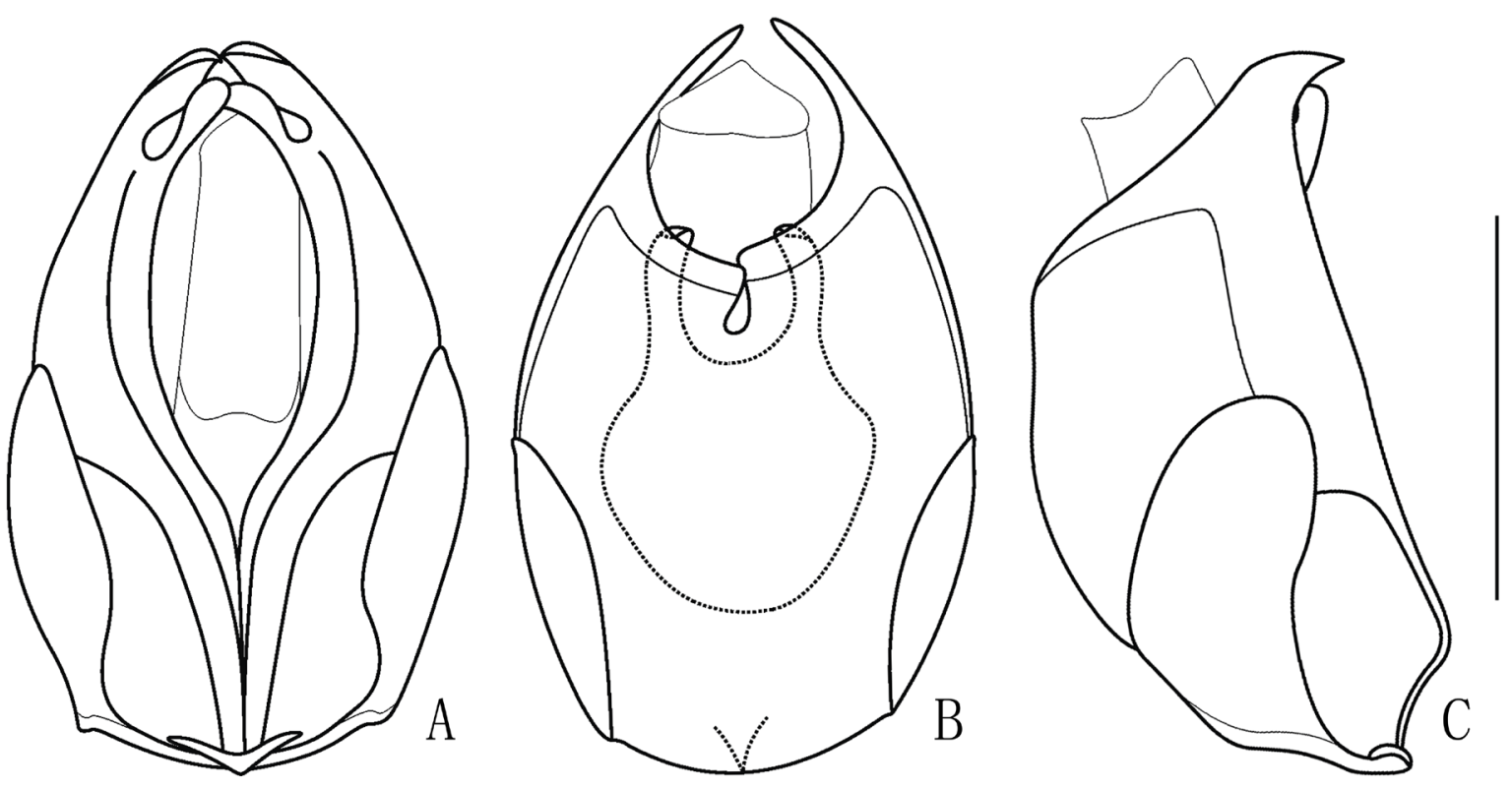

Fig. 11. Aedeagus of Stenothemus laticornis Y. Yang \& H. Liu sp. nov., holotype (MHBU HBU(E) 410045). A. Ventral view. B. Dorsal view. C. Lateral view. Scale bar $=0.5 \mathrm{~mm}$. 


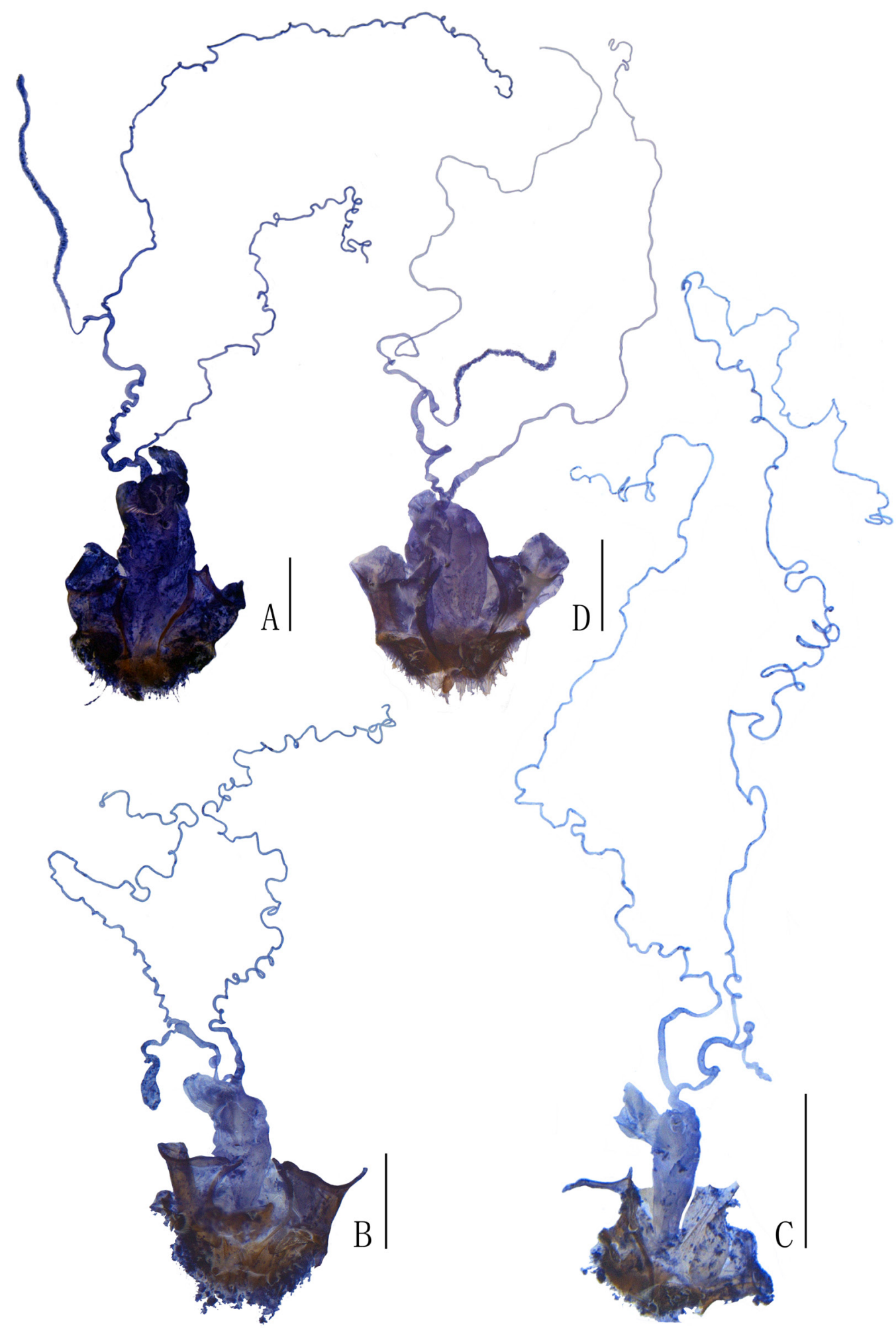

Fig. 12. Female reproductive system, ventral view. A. Stenothemus singularicollis (Pic, 1933) comb. nov. (MHBU, Shaanxi). B. S. gracilis Y. Yang \& X. Yang sp. nov., paratype (IZAS IOZ(E) 225787). C. S. flavicollis Y. Yang \& S. Ge sp. nov., paratype (MHBU HBU(E) 410039). D. S. laticornis Y. Yang \& H. Liu sp. nov., paratype (MHBU HBU(E) 410047). Abbreviations: see Material and methods. Scale bars $=0.5 \mathrm{~mm}$. 
PRonotum. Subquadrate, about 1.1 times as long as wide, anterior margin arcuate, anterior angles obtuse, subrounded, lateral margins slightly sinuate, posterior margin slightly sinuate and narrowly bordered, posterior angles sub-rectangular, disc strongly convex on posterolateral parts, surface finely and densely punctate.

ELYTRA. Nearly parallel-sided, about 3.6 times as long as humeral width, 4.6 times as long as than pronotum, surface finely and densely punctate, with hardly visible longitudinal costae.

Aedeagus (Fig. 11A-C). Moderately swollen laterally at basal part, strongly reduced in diameter apically; basal piece nearly as long as dorsal plate of each paramere, with a large, bifurcate conjoined middle nodule at base of ventral side; ventral processes of parameres strongly approaching each other, short and distinctly thickened apically, bent dorsally in lateral view; dorsal plates slightly longer than ventral processes, strongly narrowed near base, approaching each other, apex acute; apical parts of laterophyses depressed and separated from each other, apex wide-triangular and weakly exceeding middle emargination between dorsal plates.

\section{Female}

Similar to male, but body stouter than male, eyes small, less protruding, head width across eyes 1.4 times wider than pronotum, antennae shorter and roughly extending to elytral mid-length, IV-XI without impressions; elytra about 3.2 times as long as humeral width.

AbDominal sternite VIII (Fig. 7F). Moderately narrowed posteriorly, lateroapical angles widely rounded, posterior margin widely and roundly emarginate in middle and feebly sinuate on both sides, behind the notch with a membrane which is sclerotized and triangularly bilobed at apex.

INTERNAL ORGAN OF REPRODUCTIVE SYSTEM (Fig. 12D). Vagina stout, with median oviduct situated at ventroapical part, vagina abruptly narrowed in apical part and extended into a short duct which diverticulum and spermathecal duct are arising from; diverticulum moderately long, about 0.58 times adult body length, evenly thinned apically, slender tube-shaped and spiral; spermathecal duct moderately long but much shorter than diverticulum; spermatheca slender tube-shaped and spiral, obviously thinner than spermathecal duct and nearly as long as diverticulum, with basal part extended into a short tube, at opening of accessory gland. Accessory gland thin in basal part and the remainder moderately thin, obviously shorter than spermatheca.

\section{Distribution}

China (Chongqing).

\section{Key to the species of Stenothemus from Southwest China}

1. Pronotum subrounded, with protruding and acute posterior angles

- Pronotum subquadrate, with nearly rectangular and obtuse posterior angles …............................. 7

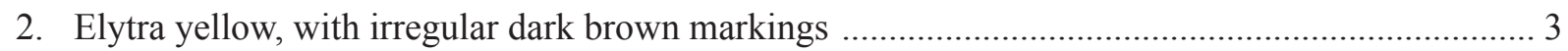

- Elytra yellow or brown, without dark markings .......................................................................... 4

3. Aedeagus (Fig. 2G-I): ventral process of each paramere nearly parallel to dorsal plate in lateral view, laterophyses feebly exceeding middle emargination between dorsal plates; female reproductive system (Fig. 4C): spermathecal duct very long, slightly longer than diverticulum

S. diffusus Wittmer, 1974

- Aedeagus (Fig. 6A-C): ventral process of each paramere at an obvious angle to dorsal plate in lateral view, laterophyses clearly exceeding middle emargination between dorsal plates; female reproductive system (Fig. 8A): spermathecal duct moderately long, much shorter than diverticulum S. grahami Wittmer, 1974 


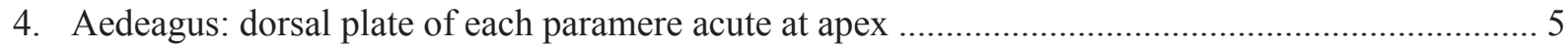

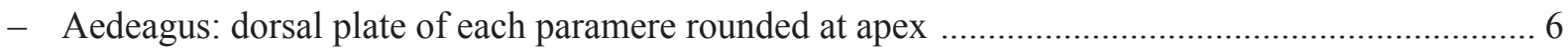

5. Body larger, more than $7.5 \mathrm{~mm}$ in length; aedeagus (Švihla 2004: figs 155-156): apical part of dorsal plate strongly narrowed, middle emargination between dorsal plates very deep, longer than half its length

S. jindrai Švihla, 2004

- Body smaller, $6.6 \mathrm{~mm}$ in length; aedeagus (Fig. 10G-I): apical part of dorsal plate slightly narrowed, middle emargination between dorsal plates moderately deep, nearly as long as half its length

S. jindraimimus Y. Yang \& X. Yang sp. nov.

6. Body yellow, pronotum darkened at anterior angles; aedeagus (Švihla 2004: figs 161-163): dorsal plates of parameres separated from each other, ventral process of each paramere slightly thickened apically

S. benesi Švihla, 2004

- Body brown, pronotum lightened at anterior angles; aedeagus (Fig. 2A-C): dorsal plates of parameres approaching each other, ventral process of each paramere distinctly thickened apically

S. shaanxiensis Švihla, 2004 stat. nov.

7. Body uniformly black (Fig. 1E)

S. dundai Švihla, 2004

- Body at least bicolored

8. Pronotum distinctly widened anteriorly; aedeagus (Fig. 6D-F): dorsal plates of parameres conjoined, with a rounded emargination in middle of apical margin ....S. minutissimus (Pic, 1933) comb. nov.

- Pronotum nearly parallel-sided; aedeagus: dorsal plates of parameres separated 9

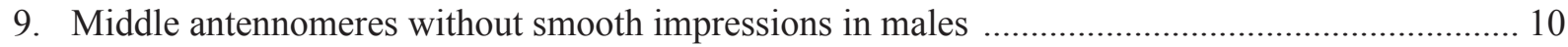

- Middle antennomeres with smooth impressions in males ..... .11

10. Head, pronotum and scutellum testaceous, elytra yellow ....S. singularicollis (Pic, 1933) comb. nov.

- Head and pronotum black brown, scutellum yellow, elytra black (Fig. 5C) ..S. tryznai Švihla, 2004

11. Antennae flattened or thickened, very long, almost reaching apices of elytra in males 12

- Antennae simple filiform, moderately long, at most extending to $3 / 4$ length of elytra in males ...... 13

12. Antennomeres IV-XI flattened; aedeagus (Fig. 11A-C): ventral process distinctly thickened apically, bent dorsally in lateral view; apex of laterophyses exceeding middle emargination between dorsal plates S. laticornis Y. Yang \& H. Liu sp. nov.

- Antennomeres IV-XI cylindrically thickened; aedeagus (Fig. 10A-C): ventral process slightly narrowed apically, bent ventrally in lateral view; apex of laterophyses not reaching middle emargination between dorsal plates

S. chongqingensis Y. Yang \& H. Liu sp. nov.

13. Pronotum yellow, nearly as long as wide; aedeagus (Fig. 10D-F): lateroapical part of dorsal plate longitudinally ridged; female reproductive system (Fig. 12C): diverticulum and spermatheca extremely long, diverticulum much shorter than spermatheca

S. flavicollis Y. Yang \& S. Ge sp. nov.

- Pronotum reddish brown or black, distinctly longer than wide; aedeagus: dorsal plate not ridged; female reproductive system: diverticulum and spermatheca moderately long, diverticulum much or slightly longer than spermatheca 14 
14. Aedeagus (Fig. 2D-F): ventral process of each paramere moderately long, apex of laterophyses not reaching middle emargination between dorsal plates; abdominal sternite VIII (Fig. 3B): lateroapical angles widely rounded, posterior margin roundly emarginate in middle, sclerotized membrane simple, without rectangular longitudinal sclerite

S. davidi (Pic, 1926) comb. nov.

- Aedeagus (Fig. 6G-I): ventral process of each paramere short, apex of laterophyses clearly exceeding middle emargination between dorsal plates; abdominal sternite VIII (Fig. 7D): lateroapical angles triangular and protruding, posterior margin rectangularly emarginate in middle, sclerotized membrane with a rectangular sclerite present at center and a small longitudinal sclerite on each side

S. gracilis Y. Yang \& X. Yang sp. nov.

\section{Note}

Stenothemus kansuensis Pic, 1933 is not included in the key because the type was not located by us.

\section{Discussion}

The diagnosis of Stenothemus, including male and female characters, has been summarized in previous works (e.g., Okushima \& Satô 1999; Yang et al. 2021). Based on these diagnostic characters, some species should be transferred to this genus; S. davidi (Pic, 1926) (from Malthacus Kirby, 1837), S. minutissimus (Pic, 1933) (from Micropodabrus Pic, 1920) and S. singularicollis (Pic, 1933) (from Lycocerus Gorham, 1895). These species have been quite poorly known since their original descriptions. Fortunately, their types are located in MNHN, and some additional specimens are at our disposal, allowing us to clarify their status and redescribe them or provide more morphological characters to recognize them.

Based on an examination and comparison of the types, S. dinshuiensis Švihla, 2011 syn. nov. is proposed as a junior synonym of $S$. davidi, and S. melleus Švihla, 2005 syn. nov. is synonymized with S. singularicollis, because insufficient differences were found to justify their separation. Stenothemus shaanxiensis Švihla, 2004 should be raised to a full species from a subspecies of S. benesi Švihla, 2004, justified by differences in external appearance and the aedeagus.

Additionally, the characters of the female genitalia are provided for some previously known species. This character is considered to be of high value in defining the subfamilies of Cantharidae by Brancucci (1980), has been used in species descriptions since Okushima (2005), and has been proved helpful in differentiating species of Stenothemus in our previous work (Yang et al. 2021; Ge et al. 2021). Thus, it is important to illustrate this structure for as many species as possible. Based on our studies, the characters of the internal reproductive system are quite stable within one species, including the number of spermatheca, the shape and relative length of the spermathecal duct, spermatheca, diverticulum and accessory gland. Usually, one well-dissected specimen is used to illustrate the characteristics of this structure for the species, but sometimes two or more examples are dissected. The spermatheca is important to maintain the viability of the spermatozoa which it stores, so a larger number of, or larger, spermathecae suggests greater reproductive potential (Paschini \& Martin 2017). Since the body length varies in the adults among the species, and the spermatheca accordingly changes in length, so the ratio between the two may reflect the reproductive ability to some extent, as discussed in this study.

Finally, on the basis of our previous work (Yang et al. 2014) and the present study, we discovered that the genus Stenothemus is much more diverse in Southwest China than in the southeastern part (Ge et al. 2021; Yang et al. 2021). Sixteen species, including five new species, are recorded here, and some further species from Yunnan and Xizang will be added in forthcoming work. The species can be identified using the key located at the end of the Results section. 


\section{Acknowledgments}

We are grateful to the late Dr Michel Brancucci (NHMB) for his great help to Y. Yang in studying the taxonomy of Cantharidae. We are also indebted to Dr Antoine Mantilleri (MNHN) and the late Dr Vladimír Švihla (NMPC) for allowing us access to the collections under their charge. We also thank Prof. Bin Chen (Chongqing Normal University, Chongqing, China) for providing us with some of the material studied, and Mr John MacDermott (USA) and the editors Dr Nesrine Akkari and Dr Max Barclay for correcting the English of the manuscript. The present study was financially supported by the National Natural Science Foundation of China (Nos 31772507, 41401064), the Natural Science Foundation of Hebei Province (Nos C201720112, C2019201192), the Biodiversity Survey and Assessment Project of the Ministry of Ecology and Environment, China (No. 2019HJ2096001006), the Science and Technology Project of Hebei Education Department (No. BJ2017030) and Post-graduate Innovation Fund Project of Hebei Province (No. HBU2021ss049).

\section{References}

Brancucci M. 1980. Morphologie comparée, évolution et systématique des Cantharidae (Insecta: Coleoptera). Entomologica Basiliensia 5: 215-388.

Delkeskamp K. 1977. Cantharidae. Editio seconda. In: Wilcox J.A. (ed.) Coleopterorum Catalogus Supplementa 165 (1): 1-485. W. Junk, The Hague.

Ge S.J., Liu H.Y., Yang X.K. \& Yang Y.X. 2021. Five new species of Stenothemus Bourgeois from Guangxi, China (Coleoptera, Cantharidae). Journal of Asia-Pacific Entomology.

https://doi.org/10.1016/j.aspen.2021.05.012

Kazantsev S.V. \& Brancucci M. 2007. Cantharidae. In: Löbl I \& Smetana A. (eds) Catalogue of Palaearctic Coleoptera, Vol. 4: 234-298. Apollo Books, Stenstrup.

Okushima Y. 2005. A taxonomic study on the genus Lycocerus (Coleoptera, Cantharidae) from Japan, with zoogeographical considerations. Japanese Journal of Systematic Entomology, Monographic Series 2: $1-383$.

Okushima Y. \& Satô M. 1999. Cantharid beetles of the genus Stenothemus (Coleoptera, Cantharidae) from Taiwan. Elytra 27 (1): 131-140.

Paschini T.V. \& Martin G.F. 2017. The insect spermatheca: an overview. Zoology 121: 56 -71. https://doi.org/10.1016/j.zool.2016.12.001

Pic M. 1926. Nouveaux coléoptères exotiques. Bulletin du Muséum d'histoire naturelle 32: 354-359.

Pic M. 1933a. Schwedisch-chinesische wissenschaftliche Expedition nach den nordwestlichen Provinzen Chinas unter Leitung von Dr. Sven Hedin und Prof. Sü Ping-chang. Insekten gesammelt vom schwedischen Arzt der Expedition Dr. David Hummel 1927-1930. 16. Coleoptera. 2. Helmidae, Dermestidae, Anobiidae, Cleridae, Malaeodermata, Dascillidae, Heteromera (ex p.), Bruchidae, Cerambycidae, Phytophaga (ex p.). Arkiv för Zoologi A27 (2): 1-14.

Pic M. 1933b. Malacodermes exotiques. L'Échange, Revue Linnéenne 49 [hors-texte] (451-454): 109-112, 113-116, 117-120.

Švihla V. 2004. New taxa of the subfamily Cantharinae (Coleoptera, Cantharidae) from southeastern Asia with notes on other species. Entomologica Basiliensia 26: 155-238.

Švihla V. 2005. New taxa of the subfamily Cantharinae (Coleoptera: Cantharidae) from south-eastern Asia with notes on other species II. Acta Entomologica Musei Nationalis Pragae 45: 71-110.

Švihla V. 2011. New taxa of the subfamily Cantharinae (Coleoptera: Cantharidae) from south-eastern Asia, with notes on other species III. Zootaxa 2895: 1-34. https://doi.org/10.11646/zootaxa.2895.1.1 
Takahashi K. 2007. Taxonomic status of Malthacus (Coleoptera, Cantharidae). Japanese Journal of Systematic Entomology 13 (2): 241-256.

Wittmer W. 1954. 13. Beitrag zur Kenntnis der indo-malayischen Malacodermata (Coleoptera). Philippine Journal of Science 83 (1): 75-81.

Wittmer W. 1969. Synonymische und systematische Notizen über Coleopteren. Mitteilungen der Schweizerischen Entomologischen Gesellschaft 42 (1-2): 126-134.

Wittmer W. 1972. Beitrag zur Kenntnis der palaearktischen Cantharidae und Malachiidae (Col.). Entomologische Arbeiten aus dem Museum G. Frey 23: 122-141.

Wittmer W. 1974. Zur Kenntnis der Gattung Stenothemus Bourg. (Col. Cantharidae). Mitteilungen der Schweizerischen Entomologischen Gesellschaft 47 (1-2): 49-62.

Yang Y.X., Su J.Y. \& Yang X.K. 2014. Review of the Stenothemus harmandi species-group (Coleoptera, Cantharidae), with description of six new species from China. Zootaxa 3847 (2): 203-220.

https://doi.org/10.11646/zootaxa.3847.2.2

Yang Y., Ge S., Yang X. \& Liu H. 2021. Review of the species of Stenothemus from Southeast China (Coleoptera, Cantharidae). European Journal of Taxonomy 744 (1): 119-144.

https://doi.org/10.5852/ejt.2021.744.1307

Manuscript received: 21 December 2020

Manuscript accepted: 13 April 2021

Published on: 25 June 2021

Topic editor: Nesrine Akkari

Section editor: Max Barclay

Desk editor: Pepe Fernández

Printed versions of all papers are also deposited in the libraries of the institutes that are members of the EJT consortium: Muséum national d'histoire naturelle, Paris, France; Meise Botanic Garden, Belgium; Royal Museum for Central Africa, Tervuren, Belgium; Royal Belgian Institute of Natural Sciences, Brussels, Belgium; Natural History Museum of Denmark, Copenhagen, Denmark; Naturalis Biodiversity Center, Leiden, the Netherlands; Museo Nacional de Ciencias Naturales-CSIC, Madrid, Spain; Real Jardín Botánico de Madrid CSIC, Spain; Zoological Research Museum Alexander Koenig, Bonn, Germany; National Museum, Prague, Czech Republic. 